\title{
Review Article \\ Epithelial Anion Transport as Modulator of Chemokine Signaling
}

\author{
Andrea Schnúr, ${ }^{1}$ Péter Hegyi, ${ }^{2,3}$ Simon Rousseau, ${ }^{4}$ Gergely L. Lukacs, ${ }^{1,5,6}$ and Guido Veit ${ }^{1}$ \\ ${ }^{1}$ Department of Physiology, McGill University, Montréal, QC, Canada H3G $1 Y 6$ \\ ${ }^{2}$ Institute for Translational Medicine and 1st Department of Medicine, University of Pécs, Pécs 7624, Hungary \\ ${ }^{3}$ MTA-SZTE Translational Gastroenterology Research Group, Szeged 6720, Hungary \\ ${ }^{4}$ The Meakins-Christie Laboratories, Research Institute of the McGill University Health Centre, Montréal, QC, Canada H2X 2P2 \\ ${ }^{5}$ Department of Biochemistry, McGill University, Montréal, QC, Canada H3G $1 Y 6$ \\ ${ }^{6}$ Groupe de Recherche Axé sur la Structure des Protéines (GRASP), McGill University, Montréal, QC, Canada H3G $1 Y 6$
}

Correspondence should be addressed to Guido Veit; guido.veit@mcgill.ca

Received 11 December 2015; Revised 3 May 2016; Accepted 12 May 2016

Academic Editor: Luciola S. Barcelos

Copyright (C) 2016 Andrea Schnúr et al. This is an open access article distributed under the Creative Commons Attribution License, which permits unrestricted use, distribution, and reproduction in any medium, provided the original work is properly cited.

\begin{abstract}
The pivotal role of epithelial cells is to secrete and absorb ions and water in order to allow the formation of a luminal fluid compartment that is fundamental for the epithelial function as a barrier against environmental factors. Importantly, epithelial cells also take part in the innate immune system. As a first line of defense they detect pathogens and react by secreting and responding to chemokines and cytokines, thus aggravating immune responses or resolving inflammatory states. Loss of epithelial anion transport is well documented in a variety of diseases including cystic fibrosis, chronic obstructive pulmonary disease, asthma, pancreatitis, and cholestatic liver disease. Here we review the effect of aberrant anion secretion with focus on the release of inflammatory mediators by epithelial cells and discuss putative mechanisms linking these transport defects to the augmented epithelial release of chemokines and cytokines. These mechanisms may contribute to the excessive and persistent inflammation in many respiratory and gastrointestinal diseases.
\end{abstract}

\section{Introduction}

The ion and water homeostasis, mediated by channels and transporters at the apical and basolateral membranes of secretory epithelia that maintain a fluid compartment at the luminal surface, is essential for the function of different organ systems such as the airways, intestines, and pancreas $[1,2]$. The most abundant anions, chloride and bicarbonate, are secreted through the apical cystic fibrosis transmembrane conductance regulator (CFTR) and calcium-activated chloride channel TMEM16A and anion exchangers of the SLC26A family. At the basolateral plasma membrane (PM) chloride and bicarbonate uptake are mediated by the sodium-potassiumchloride cotransporter (NKCC1) and sodium-bicarbonate cotransporters (NBC1), respectively [1] (Figure 1). Alternatively, basolateral chloride entry into the cell is conducted by the basolateral chloride-bicarbonate exchanger AE2 [3].
Secretory epithelial cells also play a pivotal role as part of the innate immune system. Besides providing a physical barrier by forming tight cell-cell contacts and a chemical barrier by secreting antimicrobial peptides and mucins, epithelial cells express a variety of pattern-recognition receptors that, when triggered, activate the expression and release of a number of chemokines and cytokines. These inflammatory mediators in concert with the production of reactive oxygen species (ROS) allow the epithelium to contribute to the host defense and to recruit specialized immune cells [47]. It is well established that the expression and function of ion channels and transporters, including the anion channel and transporters discussed in this review, are modulated by chemokines and cytokines [8-12]. Examples for these mechanisms include the inhibition and downregulation of the epithelial sodium channel $(\mathrm{ENaC})$ by IL-4 and IL-13 $[10,13,14]$, the IL-4 and IL-13-mediated increase in function 
and expression of CFTR [13], and TMEM16A [15] as well as pendrin (SLC26A4) [12, 16] and SLC26A9 [17]. The CFTR expression and activity are increased by $\mathrm{TNF} \alpha$ [18] and decreased by $\operatorname{IFN} \gamma[19,20]$ and its function is attenuated by CXCL8 via $\beta 2$-adrenergic receptor $(\beta 2$-AR) dependent mechanism [21] (Figure 1).

In contrast, little is known about the regulatory role of anion transport on cytokine, in particular chemokine, synthesis, and secretion of epithelial cell that serves as amplifier and regulator of inflammation in conditions like cystic fibrosis (CF), chronic obstructive pulmonary disease (COPD), asthma, cholestasis, and acute pancreatitis. The effects of aberrant anion transport activities in these diseases and putative mechanisms linking them to the augmented epithelial release of chemokines and cytokines are discussed in this review.

\section{Diseases Exhibiting Defective Epithelial Anion Transport}

2.1. Cystic Fibrosis. Cystic fibrosis (CF), the most common lethal hereditary disease in the Caucasian population, is caused by mutations in CFTR that lead to impaired anion conductance at the apical membrane of secretory epithelia [22-25]. More than 2,000 mutations in CFTR have been described that confer a range of molecular, cellular, and functional phenotypes [26, 27] and can be classified according to these complex phenotypes as recently reviewed [28]. Interestingly, mutants that are expressed at the apical membrane in densities comparable to the wild-type (WT) protein but are nonfunctional (e.g., G551D-CFTR) cause a similar CF disease severity as mutants with strongly reduced protein at the PM (e.g., $\Delta$ F508-CFTR) [27, 29], suggesting that the loss of CFTR function rather than its physical absence is required for the initiation of the disease.

CF is characterized by a multiorgan pathology mainly affecting the upper and lower airway, gastrointestinal and reproductive tract, and endocrine system [23, 25]. Pancreatic disease in CF has a high penetrance and the pancreas is the earliest intrauterine affected organ [30, 31]. Most CF patients (80-90\%) suffer from pancreatic insufficiency (PI), a condition characterized by acinar atrophy, ductal irregularity, fibrosis, deficiency of exocrine pancreatic enzymes, and beta cell damage at late stages. Importantly, the level of pancreatic damage in CF is linked to the genotype $[32,33]$. Patients that retain sufficient exocrine pancreatic function carry a small risk to develop pancreatitis $[34,35]$. In the lung, imbalanced epithelial ion secretion and mucus thickening lead to decreased airway clearance and reoccurring bronchopulmonary infections that cumulate in tissue damage, the leading cause for morbidity and mortality in CF [36-39].

It is widely accepted that CF lung disease is associated with an excessive inflammatory response that is characterized by massive neutrophil recruitment into the lumen driven by augmented release of chemokines including CXCL8 by lung epithelial tissue. Once recruited and activated the neutrophils release antimicrobial peptides, neutrophil extracellular traps (NETs), reactive oxygen species, and proteases [40-42]. The sheer amount of neutrophil released serine proteases (neutrophil elastase (NE), proteinase 3 , and cathepsin $\mathrm{G}$ ) overwhelms the antiprotease production resulting in proteaseantiprotease imbalance $[43,44]$. Excessive amounts of $\mathrm{NE}$ in the airway-surface liquid in turn induce CXCL8 expression $[45,46]$, upregulate mucin production $[47,48]$, cleave antimicrobial peptides [49], and promote the degradation of CFTR [50] further perpetuating the inflammatory response that cumulates in progressive tissue damage. Despite their excessive infiltration into the CF lung, CF neutrophils fail to eradicate bacterial infections [41, 51]. A recent study shows that CF neutrophils exhibit abnormal degranulation responses and consequently impaired bacterial killing. Treatment of G551D-CFTR patient with the potentiator ivacaftor normalized the intracellular homeostasis and degranulation of their neutrophils, thus improved bacterial killing [52]. These findings and studies reporting reduced phagolysosomal chlorination in CF neutrophils $[53,54]$ suggest an intrinsic neutrophil function defect in CF. However, although hyperinflammation in CF is acknowledged, it is under debate whether the immunological aberrancy is directly caused by loss-of-CFTR-function or is rather the consequence of chronic bacterial infection (this controversy is reviewed in $[42,55-57])$.

2.1.1. Animal Models of CF. Animal models allow investigating the early pathogenesis of $\mathrm{CF}$ and examining how the lack of CFTR is linked to the host-defense defect of the lung. Several CF mouse models exist, including null $[58,59]$ and mutant form of CFTR [60-62] expressing animals. However, none of these models develops spontaneous severe lung disease, characteristic of human CF. Yet CF mice do secrete dramatically higher concentrations of inflammatory mediators upon bacterial challenge, including the chemokines keratinocyte chemoattractant (KC/CXCL1, the functional CXCL8 analog in mice) and the macrophage inflammatory protein 2 (mip-2/CCL3) that can be measured in the bronchoalveolar lavage (BAL) fluid [63, 64]. Concordantly, inhibition of CFTR in WT mice using the inhibitor-172 exacerbates the acute inflammatory response in an induced peritonitis model, including increased polymorphonuclear leukocyte infiltration and cytokine release [65]. The specificity of the inhibitor-172 however is questioned by other studies [66-68]. Transgenic mice that overexpress the $\beta$-subunit of the epithelial sodium channel (ENaC) in the airway, mimicking the increased sodium reabsorption found in human airway epithelia by many researchers [36, 37, 69], exhibit mucus obstruction, goblet cell metaplasia, increased BAL levels of the chemokines CXCL1 and CXCL2, neutrophilic inflammation, and poor bacterial clearance [70].

Since mice do not recapitulate all of the hallmarks of human $\mathrm{CF}$, considerable efforts were made to create other animal models. CFTR ${ }^{-/-}$rats were recently created using DNA editing and the resulting animals show a reduced airway-surface liquid (ASL) height and submucosal gland hypoplasia [71]. $C F T R^{-/-}$and $C F T R^{\triangle F 508 / \triangle F 508}$ pigs as well as $C F T R^{-/-}$ferrets were generated by adeno-associated virusmediated gene targeting and somatic cell nuclear transfer $[72,73]$. CF pigs and ferrets develop spontaneous lung disease 


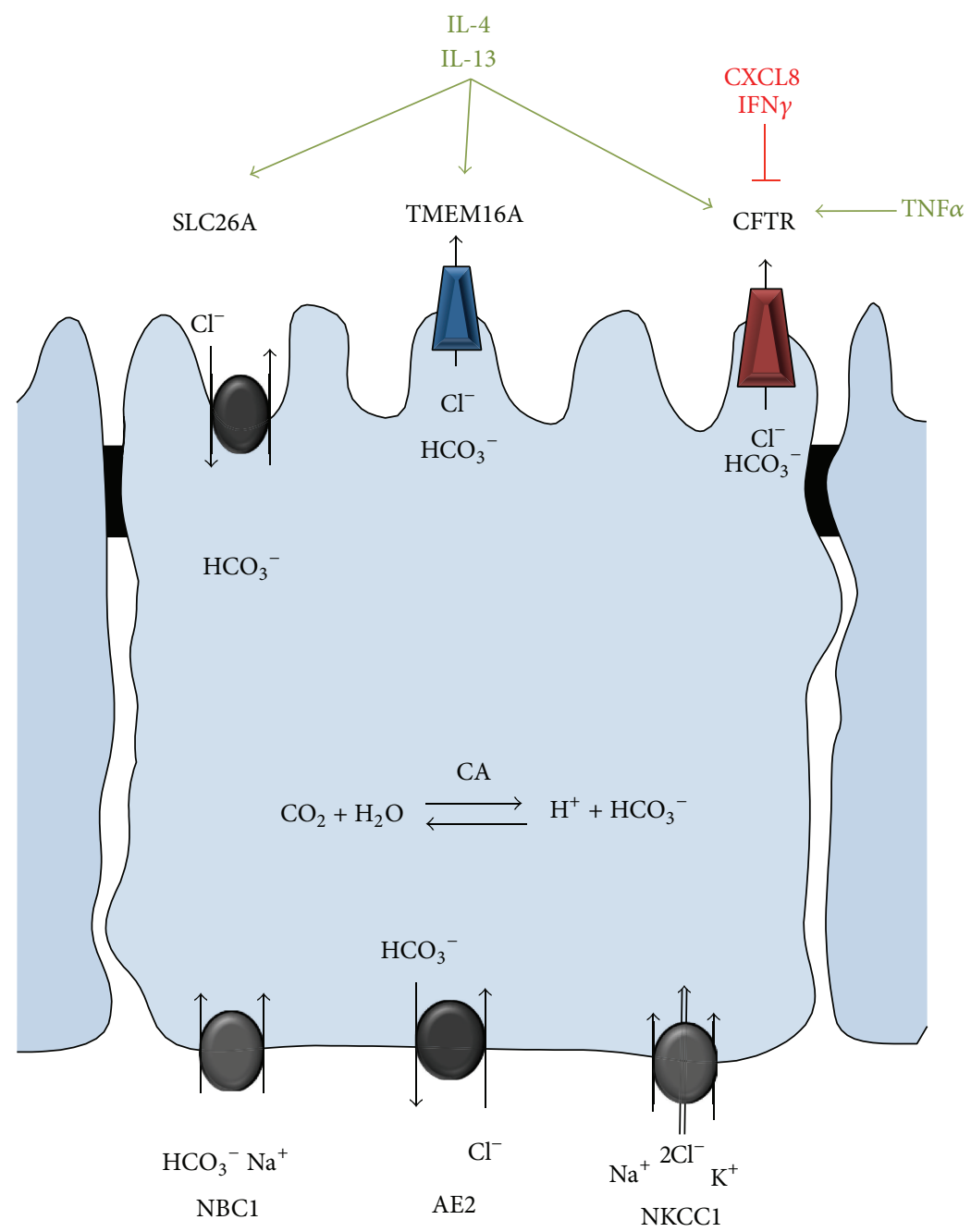

FIGURE 1: Schematic depiction of the anion transport pathways in secretory epithelia. Apical chloride $\left(\mathrm{Cl}^{-}\right)$and bicarbonate $\left(\mathrm{HCO}_{3}{ }^{-}\right)$efflux is mediated by CFTR and TMEM16A and probably members of the SLC26A family. Basolateral chloride and bicarbonate entry is conducted by cation cotransporters $\mathrm{NKCCl}$ and $\mathrm{NBCl}$, respectively. Alternatively chloride entry at the basolateral membrane is conducted by chloridebicarbonate exchange via AE2. Carbonic anhydrase (CA) catalyzes the de novo formation of bicarbonate. Examples for the cytokine-mediated regulation of channel function or expression are indicated.

characterized by airway inflammation, airway remodeling, impaired mucosal clearance, and bacterial infection [7476]. The clearance upon bacterial challenge in the lung of both animal models is impaired likely as a result of the decreased $\mathrm{pH}$ and therefore attenuated antibacterial properties of the ASL [77, 78]. The onset of pulmonary inflammation however differs between CF pigs and ferrets. The CXCL8 and TNF $\alpha$ levels were increased in the CF ferret BAL at birth, suggesting an inherent innate immunity defect [77]. In contrast neutrophil counts and CXCL8 levels were not augmented in the neonatal CF pig BAL $[74,76]$. Intriguingly, the pancreas of newborn CF pig shows increased proportion of innate immune cells and inflammatory response without apparent infection [79]. Similarly, zebrafish that lacks functional CFTR shows progressive destruction of the exocrine pancreas accompanied by a significant increase in neutrophil infiltration [80]. Thus, upregulation of chemokine secretion that promotes neutrophil recruitment likely contributes to the early onset of inflammation in these animals.

2.1.2. Human Studies. An early onset of excessive proinflammatory chemokine and cytokine release into the BAL of CF infants has been reported, but whether this precedes bacterial infection remains controversial [81-85]. CXCL8, neutrophils counts, and the concentration of free elastase were prominently increased in the BAL of CF patients in comparison to healthy controls $[82-84,86]$. Other inflammatory mediators that are augmented in the CF lung include IL- 6 , IL- $1 \beta$, and TNF- $\alpha$ [87], GM-CSF and G-CSF [88], IL-33 [89], HMGB1 [90], and the chemokine CCL18 [91]. Interestingly, a number of studies reported a decrease of the anti-inflammatory cytokine IL-10 in CF BAL [87, 92, 93]. By binding to the IL10 receptor, IL-10 inhibits signaling pathways including the mitogen-activated kinase $\mathrm{p} 38$ and NF- $\kappa \mathrm{B}$ pathways that are 
associated with proinflammatory chemokine and cytokine expression.

Using tracheal or bronchiolar grafts from CF and nonCF human foetuses implanted into severe combined immunodeficient (SCID) mice Tirouvanziam and colleagues investigated the inflammatory state prior to any infection $[94,95]$. Both upper and lower airway CF grafts showed increased CXCL8 expression and leukocyte infiltration, but the inflammation was more severe in the bronchiolar grafts leading to progressive tissue destruction. These results provide evidence that CF lung inflammation could arise solely from CFTR mutations in sterile environment.

2.1.3. Cell Models. Increased CXCL8 expression in CF cell lines and CF primary human bronchial epithelial cells has been reported, both constitutively and following stimulation with Pseudomonas aeruginosa or TNF- $\alpha$, implying CFTRdependent alteration in the innate immune response [9698]. However, elevated CXCL8 levels were not observed in other cellular models [99-101], while in some studies CFTR appeared to have a permissive role in CXCL8 secretion $[102,103]$. The interpretation of these results is difficult since many derive from the comparison between clonally isolated $\mathrm{CF}$ and non-CF cell lines. Isolation of individual clones from heterologous cell populations, however, may favor unrepresentative phenotypes as clonal variations can exceed the underlying differences in the regulated CXCL8 secretion [67]. The genetic heterogeneity and possible epigenetic modification due to the repeated infection and inflammation in CF [104] restrict the comparability of primary human cells from CF patients and healthy individuals. However, a number of studies elegantly circumvented these limitations. Inhibition of CFTR function by continuous treatment with the inhibitor-172 in differentiated primary airway epithelial cells resulted in increased constitutive CXCL8 secretion that was further augmented by Pseudomonas aeruginosa infection [105]. CFTR inhibition by gene knockdown in the human intestinal epithelial cell lines Caco-2/15 and HT-29 [106] as well as in human the human airway epithelial cell line Calu-3 [107] similarly increased CXCL8 secretion. In another approach human CF respiratory epithelial models with the inducible expression of either CFTR or TMEM16A were generated. Induced expression of WT-CFTR or TMEM16A attenuated the proinflammatory chemokine CXCL8, CXCL1, and CXCL2 and cytokine IL- 6 expression under air-liquid, but not liquid-liquid interface culture [67]. Likewise, transient lentiviral transduction that conferred the expression of WT-CFTR reduced CXCL8 secretion of primary human CF bronchial epithelia [67]. Interestingly, the expression of the nonfunctional G551D-CFTR or WT-CFTR in combination with channel inhibition failed to attenuate CXCL8 release, suggesting that CFTR-mediated anion transport activity at the apical PM is required to reduce the proinflammatory chemokine and cytokine secretion [67].

2.2. Chronic Obstructive Pulmonary Disease. Chronic obstructive pulmonary disease (COPD), encompassing two clinical phenotypes, chronic bronchitis, and emphysema, is attributed to the exposure to cigarette smoke and other environmental toxins $[108,109]$. Genetic factors such as $\alpha 1-$ antitrypsin gene mutations are also associated with disease [110]. COPD affects 64 million people and currently is the 4th leading cause of mortality worldwide [111]. COPD is characterized by persistent airflow limitation, chronic inflammatory responses, excessive mucus production, and recurrent cough, concordant to the CF lung phenotype. COPD shares several other clinical, immunological, and biochemical features with CF. Both are characterized by reduced mucociliary clearance, goblet cell metaplasia, chronic bacterial infections, excessive innate immune responses, and persistent neutrophilic inflammation. In comparison with CF, however, the inflammatory response in COPD includes more pronounced involvement of the adaptive immune system. An inverse correlation between the number of CD8+ T cells and the $\mathrm{CD} 4+/ \mathrm{CD} 8+$ ratio to the lung function has been observed [112-114]. The CD8+ $\mathrm{T}$ cells release perforins and cause cytolysis and apoptosis of alveolar epithelial cells that is correlated to emphysema $[115,116]$.

The phenotypic similarity between CF and COPD raises the possibility that CFTR inactivation and/or downregulation may play an important role in the pathogenesis of COPD. Indeed, a number of studies support this hypothesis. (i) COPD disease severity is inversely correlated with CFTR protein expression [117]. (ii) CFTR function and expression are markedly attenuated in the respiratory epithelia of smokers and patients suffering from COPD [118, 119]. (iii) CFTR downregulation was observed upon cigarette smoke or cigarette smoke extract exposure of respiratory and intestinal epithelial cultures [120-122]. (iv) Cigarette smoke decreases the level of CFTR in lipid rafts in mice leading to defective autophagy [123]. Overall, these studies suggest that an acquired loss of CFTR function might contribute to the pathogenesis of COPD.

The inflammation characteristics of COPD also resemble that seen in CF. Cigarette smoke extract and acrolein, a smoke component, have been shown to increase the CXCL8 mRNA stability by activating the $\mathrm{p} 38 \mathrm{MAPK} / \mathrm{MK} 2$ signaling pathway [124]. Gene expression levels of CXCL8, IL-6, CCL2, and CCL8 were elevated in both smokers and COPD patients [125]. This is consistent with the increased levels of CXCL1, CXCL8, and CCL2 in induced sputum and/or BAL fluid [109] and the augmented levels of CCL18 in the serum of COPD patients [126].

2.3. Asthma. Asthma affects approximately 300 million people worldwide. Between 5 and $15 \%$ are classified as severe asthmatics, specified by a state of heightened morbidity that is refractory to normal pharmacological treatment. Asthma is characterized by airway hyperresponsiveness (AHR), tissue remodeling as indicated by an increased proportion of airway smooth muscle in the airway wall [127], and chronic airway inflammation that together results in reversible airflow obstruction [128]. In severe asthmatics' sputa, besides hallmarks of allergic inflammation, there is increased neutrophil presence that is correlated with lowest lung function and worst asthma control [129]. The increase in smooth muscle mass leads to more airway constriction and contributes to the inflammatory milieu, including synthesis of the neutrophil 
chemoattractant CXCL8 in severe asthmatics [130]. Recent studies in the CFTR knockout pig [131] and using TMEM16A inhibitors in mouse and human airway smooth muscle [132, 133] support a role of these anion channels in smooth muscle hyperresponsiveness. Moreover, as described in the previous sections, links between defects in anion transport in epithelial cells and increased CXCL8 production may have interesting parallels in asthmatic airway smooth muscle to regulate the inflammatory milieu, particularly in severe asthmatics. The intricate connection between inflammation and anion transport in airway smooth muscle is reviewed elsewhere [134].

Current understanding suggests that beyond the smooth muscle phenotype, the airway epithelium is a key player in the pathology of asthma [135]. In addition to goblet cell hyperor metaplasia and mucus hypersecretion [136-138], the asthmatic airway epithelium exhibits barrier defects $[139,140]$ and increased release of the chemokines and cytokines CXCL8, IL-6, GM-CSF, TGF- $\beta 1$, IL-13, and IL- $1 \beta[141,142]$ that are capable of triggering both allergic (Th2-mediated [143]) and neutrophilic (Th17-mediated [144]) inflammation. Moreover, the ratio of CXCL8 to the anti-inflammatory lipid mediator lipoxin A4 is increased in severe asthmatics, favoring proinflammatory environment that promotes neutrophil recruitment [145]. Eicosanoids synthesis occurs via the cellular cooperation between structural cells (such as epithelial cells) and immune cells (like neutrophils). Changes in substrate availability (arachidonic acid (AA) versus docosahexaenoic acid (DHA)) can skew the inflammatory response, with allergic individual showing lower levels of DHA [146]. In a murine model of asthma, the proinflammatory balance was reversed using the vitamin A-derivative fenretinide to favor DHA over AA [147].

Some of these epithelial defects are reminiscent of the changes observed in cystic fibrosis. For example, in CF imbalance increasing the AA/DHA ratio has also been observed [148] that can be ameliorated with fenretinide in a CF mouse model [149]. Indeed at least 50\% of CF patients show signs of airway hyperresponsiveness and bronchodilator treatmentreversible airway obstruction [150-153], a condition referred to as "CF asthma" $[154,155]$. Concordantly, studies found an increased percentage of asthma patients to be carriers of mutations in CFTR [156-158] and the nasal potential difference values of some of these patients scored in the CF range [157]. In addition to CFTR, the involvement of anion transport in the pathophysiology of asthma is suggested by aberrant expression of other epithelial anion transporters. (i) The expression of the anion exchanger pendrin (SLC26A4) that functions to import chloride from the ASL in exchange to bicarbonate and thiocyanate [159] is upregulated in the asthmatic airway epithelium likely as a consequence of Th2 cytokine (IL-4 and IL-13) signaling [160, 161]. Interestingly, pendrin overexpression alone is sufficient to trigger mucus hypersecretion, hyperresponsiveness, and elevated secretion of the chemokines CXCL1 and CXLC2 that in turn lead to neutrophil infiltration into the airway [162]. (ii) A polymorphism in the $3^{\prime}$ UTR of SLC26A9 that functions as CFTRregulated chloride-bicarbonate exchanger or chloride channel [163-165] is associated with reduced protein expression and an increased risk for asthma [17]. (iii) The calciumactivated chloride channel TMEM16A expression in airway secretory cells is increased in asthma and correlates with mucus hypersecretion [132].

Taken together these evidences show an important role of the airway epithelium to regulate the inflammatory balance in asthma in addition to mucus hypersecretion. Thus, anion transport can significantly influence neutrophil recruitment via increased chemokine synthesis, which is particularly important for the more severe form of the disease.

2.4. Pancreatitis. Acute pancreatitis (AP) is a sudden inflammatory disorder of the pancreas. AP is one of the most common disorders requiring acute hospitalization among the GI diseases [166]. In its chronic form, pancreatitis (CP) can lead to decreased quality of life with continuous pain, diarrhoea, maldigestion, and consequently weight loss. Moreover in some cases, on the base of chronic inflammation, pancreatic ductal adenocarcinoma can develop. The human exocrine pancreas consists of two main secretory cell types: ductal and acinar cells. The two cell types, as a functional unit, interact closely to mediate the secretion of the pancreatic juice and have a conjoint role in the pathogenesis of pancreatitis [167]. Acinar cells synthetize, store, and secrete digestive zymogens that under physiological conditions are carried along the ductal system into the duodenum. AP originates from the premature activation of pancreatic zymogens, leading to the autodigestion of the pancreas that causes the recruitment of inflammatory cells. In addition, acinar cells produce a large amount of protons which are secreted with the pancreatic zymogens resulting in acidic fluid [168]. Ductal cells secrete a bicarbonate-rich, alkaline fluid that is required to neutralize the acinar acid load and carry the zymogens into the duodenum and that acts as a protective mechanism to prevent premature zymogen activation [169]. The ductal secretion contains up to $140 \mathrm{mM} \mathrm{HCO}_{3}{ }^{-}$that is achieved by the concerted activity of anion transporters. Basolateral $\mathrm{Na}^{+}-\mathrm{HCO}_{3}{ }^{-}$cotransporters, $\mathrm{Na}^{+} / \mathrm{H}^{+}$exchangers, and $\mathrm{H}^{+}$ATPases mediate $\mathrm{HCO}_{3}{ }^{-}$uptake into the epithelial cells. On the luminal side CFTR in concert with SCL26A family $\mathrm{Cl}^{-} / \mathrm{HCO}_{3}{ }^{-}$exchangers, specifically SLC26A6 (PAT1) and SLC26A3 (DRA), mediate the bicarbonate secretion. DRA serves as $2 \mathrm{Cl}^{-} / 1 \mathrm{HCO}_{3}{ }^{-}$exchanger, whereas PAT1 functions with $1: 2 \mathrm{Cl}^{-}: \mathrm{HCO}_{3}{ }^{-}$stoichiometry that enables reaching the high bicarbonate concentration characteristic for the pancreatic juice $[170,171]$. A direct molecular interaction between CFTR and SLC26A6 and A3 has been observed that results in reciprocal activation of both CFTR and the $\mathrm{Cl}^{-} / \mathrm{HCO}_{3}{ }^{-}$exchangers $[172,173]$. However, until now the exact role of SLC26A6 and SLC26A3 in the pancreatic ductal bicarbonate secretion remains controversial [174].

Etiological factors for AP mainly include biliary disease and alcohol consumption. Interestingly, these factors have been shown to impair the ductal bicarbonate transport. (i) Ethanol and its nonoxidative metabolites decrease the CFTR activity, mRNA expression, and its stability at the PM $[175,176]$. (ii) At high concentration nonconjugated bile acids impair the ductal bicarbonate and fluid secretion by inhibiting ion transporters $\left(\mathrm{Na}^{+} / \mathrm{H}^{+}\right.$exchangers, 
$\mathrm{Na}^{+}-\mathrm{HCO}_{3}{ }^{-}$cotransporters, and $\mathrm{Cl}^{-} / \mathrm{HCO}_{3}{ }^{-}$exchangers) and by causing intracellular calcium overload that leads to mitochondrial damage and ATP depletion and could also affect CFTR [177-180]. (iii) Recent studies suggest that smoking increases the risk for pancreatitis [181-183]. Acrolein, a component of cigarette smoke, has a systematic inhibitory effect on CFTR activity [184] and therefore likely contributes to the CFTR inhibition in pancreatic ducts. (iv) Intraacinar [185] or intraductal [186, 187] premature activation of trypsinogen to trypsin is a key event in the initiation of pancreatitis. Trypsin inhibits CFTR-mediated ion transport by a PAR-2 dependent pathway, thus leading to a decreased luminal $\mathrm{pH}$ that further accelerates the trypsinogen autoactivation [169]. (v) Lastly, heterozygous carriers of CFTR mutations have increased risk to develop pancreatitis [188197]. The consequences of CFTR mutations on pancreatic function include high protein content and low-flow secretion that frequently results in obstruction and the destruction of the gland. Most CF patients with pancreatic insufficiency (PI) carry "severe" mutations on both alleles that result in the loss of exocrine function. In case "severe" CFTR mutation on one allele is paired with "mild" CFTR mutation on the second allele, most patients retain sufficient exocrine function for digestion, referred to as pancreas sufficient phenotype (PS) [198-200]. Because the exocrine function is necessary for the initiation of pancreatitis, the risk for pancreatitis is higher for those mutations manifesting in PS CF phenotype [201]. Interestingly, the CFTR variant $\mathrm{R} 75 \mathrm{Q}$, which has selective bicarbonate transport defect, is associated with pancreatitis but not classical CF. Overall, the aforementioned studies indicate that the alteration of pancreatic ductal anion transport plays a role in the development of pancreatitis, suggesting that CFTR could be a possible therapeutic target for AP [32].

AP results in local and systematic overproduction of inflammatory mediators [202]. Characteristic hallmark of the disease is the increased serum levels of CXCL8 and IL- 6 as well as often IL- 1 and TNF- $\alpha$. CXLC8 and IL6 serum levels correlate with disease severity $[203,204]$. Similar to the CF airway epithelia, it is likely that the pancreatic epithelium itself is at least partly accountable for the augmented chemokine and cytokine production and therefore plays a role in the exacerbation of the pancreatic inflammation. This is supported by the expression of IL33, IL-6, and CXCL8 in stressed acinar cells [205-208] as well as CXCL8 expression in pancreatic duct cells [209]. Furthermore, pancreatic ductal adenocarcinoma cell lines (CAPAN-1 and CAPAN-2) exhibit basal and LPS induced secretion of CXCL8 and IL-6 [210]. The results of these studies raise the intriguing possibility that impaired anion transport in the pancreatic ductal system could increase chemokine and cytokine secretion and therefore contribute to the progression of pancreatitis.

2.5. Cholestatic Liver Disease. Cholangiopathies, chronic progressive liver diseases (e.g., primary sclerosing cholangitis or primary biliary cirrhosis) characterized by chronic cholestasis, are frequently caused by drugs and antibiotics and are common in CF increasing the risk for mortality
[211]. Cholestasis is bile flow stagnation that could result from either the failure of the bile formation in the liver cells (intrahepatic) or the blockade of the ductal secretory mechanism (extrahepatic), responsible for washing biliary secretion away from the hepatocytes. CFTR is expressed at the apical membranes of cholangiocytes and the gallbladder epithelium [212], where it acts as chloride channel. CFTR promotes chloride efflux to generate a luminal chloride gradient, the driving force for bicarbonate secretion via AE2 mediated chloride/bicarbonate exchange resulting in bicarbonate-rich choleresis [213, 214]. CFTR also regulates cholangiocyte secretion by stimulating ATP release into the ductal lumen. Luminal ATP triggers apical P2Y receptors resulting in calcium mobilization, which in turn activates TMEM16A-mediated bicarbonate secretion [215]. Accordingly, dysfunction of CFTR results in low ductal $\mathrm{pH}$, thickened bile, impaired bile flow, and biliary obstruction [216, 217]. This condition leads to accumulation of hydrophobic bile acids and results in periductal inflammation [218, 219].

Similar to the lung epithelium, human biliary epithelial cells participate in the innate immunity. They express various Toll-like receptors and secrete chemokines and cytokines as well as antimicrobial factors [220]. Therefore these cells play a crucial role in the pathogenesis of different cholangiopathies, such as primary biliary cholangitis and biliary atresia [221223]. Cultured biliary ductal epithelial cells secrete CXCL8 and CCL2 [224, 225] that drive neutrophil infiltration [226]. In addition several other chemokines, including CXCL1, CXCL5, CXCL6, CCL3, CCL4, CCL5, and CXCL10, are expressed by human biliary epithelial cells under both basal and stimulated conditions [227].

One study showed that a combination of proinflammatory cytokines inhibits bile ductular secretion through attenuating AE2 and CFTR function that is impeded by the inhibition of cAMP formation in isolated single biliary ductal units [228]. Other studies however highlighted the role of CFTR function in the innate immune response of the biliary epithelium. Dextran sodium sulphate induced colitis results in an induced inflammatory cholangiopathy in CF but not WT mice $[229,230]$. Indeed, downregulation of CFTR in progressive familiar intrahepatic cholestasis and reduced AE2 in primary biliary cirrhosis patients have been reported [231, 232]. Additionally, non-CF-causing CFTR mutations have been associated with primary sclerosing cholangitis in some patients $[233,234]$, further supporting the role of CFTR in these diseases.

\section{Putative Mechanisms Linking Aberrant Anion Transport to the Dysregulated Epithelial Chemokine Release}

The inherited (CF) or acquired (COPD, asthma, pancreatitis, and cholestasis) loss of epithelial anion transport is correlated to the increased inflammation driven by the release of chemokines and subsequent immune cell infiltration of the respective organs (Table 1). While in some of the discussed diseases the causality of these events is incompletely established, there is little doubt that loss of epithelial CFTR 
TABLE 1: Anion transport activity changes and proinflammatory chemokine and cytokine secretion in different diseases.

\begin{tabular}{|c|c|c|c|}
\hline & Disease & Transporter/channel function & $\begin{array}{c}\text { Augmented } \\
\text { chemokines/cytokines }\end{array}$ \\
\hline \multirow{3}{*}{ Airway system } & $\mathrm{CF}$ & CFTR $\downarrow$ & $\begin{array}{l}\text { CXCL8, CXCL1, CXCL2, CCL3, } \\
\text { CCL18, IL-1 } \beta \text {, IL-6, IL-33, TNF } \alpha \text {, } \\
\text { GM-CSF, G-CSF, HMGB1 }\end{array}$ \\
\hline & COPD & CFTR $\downarrow$ & $\begin{array}{l}\text { CXCL8, CXCL1, CCL2, CCL8, } \\
\text { CCL18, IL-6 }\end{array}$ \\
\hline & Asthma & $\begin{array}{c}\text { CFTR* }^{*} \\
\text { SLC26A4 } \uparrow \\
\text { TMEM16A } \uparrow \\
\text { SLC26A9 } \downarrow \\
\end{array}$ & $\begin{array}{l}\text { CXCL8, IL-1 } \beta, \text { IL-6, IL-13, } \\
\text { TGF- } \beta 1, \text { GM-CSF }\end{array}$ \\
\hline \multirow{2}{*}{ Gastrointestinal system } & Pancreatitis & $\begin{array}{c}\text { CFTR* }^{*} \\
\text { CFTR } \downarrow \\
\text { SLC26A3/A6 } \downarrow\end{array}$ & CXCL8, IL-1, IL-6, TNF- $\alpha$ \\
\hline & Cholestatic liver diseases & $\begin{array}{l}\text { CFTR }^{*} \\
\text { CFTR } \downarrow \\
\text { AE2 } \downarrow\end{array}$ & $\begin{array}{c}\text { CXCL8, CXCL1, CXCL5, CXCL6, } \\
\text { CXCL10, CCL2, CCL3, CCL4, } \\
\text { CCL5, }\end{array}$ \\
\hline
\end{tabular}

CFTR* : carriers of CFTR mutations have an increased risk to develop disease.

TABLE 2: Clinical trials for CF therapy indirectly targeting the lack of CFTR-mediated anion transport in the lung by ion-replacement or activation of alternative anion channels.

\begin{tabular}{|c|c|c|c|c|}
\hline Therapeutic approach & Compound & $\begin{array}{c}\text { Type of } \\
\text { administration }\end{array}$ & Result & References \\
\hline Mucus rehydration & $\begin{array}{l}\text { Hypertonic } \\
\text { saline }\end{array}$ & Nebulized & $\begin{array}{l}\text { Modest increase } \\
\text { in lung function }\end{array}$ & {$[241,242]$} \\
\hline \multirow[t]{2}{*}{$\begin{array}{l}\text { Antioxidant } \\
\text { treatment }\end{array}$} & GSH & Nebulized & $\begin{array}{l}\text { Small or no } \\
\text { effect on lung } \\
\text { function }\end{array}$ & {$[288,289,312]$} \\
\hline & $\mathrm{N}$-acetylcysteine & Oral & $\begin{array}{l}\text { Modest increase } \\
\text { in lung function }\end{array}$ & {$[291,294]$} \\
\hline TMEM16A function & Denufosol & Inhaled & $\begin{array}{l}\text { Small or no } \\
\text { effect on lung } \\
\text { function }\end{array}$ & {$[305,313]$} \\
\hline
\end{tabular}

function is the primary cause for CF. This raises the question how the lack of anion transport leads to the described disease pathogeneses or more specifically which chemical or physical alterations, caused by the lack of chloride, bicarbonate, or other anion transport, trigger the disease mechanisms.

3.1. Chloride Transport. The loss of CFTR-mediated chloride transport resulting in a decreased ASL height was proposed as primary causes of impaired mucociliary clearance, recurrent bacterial infection, and chronic neutrophilic lung infiltration in CF $[36,235,236]$. Reduced ASL height was observed in primary human CF airway epithelial cultures [236], human CF airway biopsies [237], CF ferret tracheas [77], and CF rat tracheas [71]. However, it is under debate whether CFTR inhibits the ENaC channel to prevent sodium hyperabsorption, which if this inhibition is lost contributes to the decreased ASL height [235, 238-240]. To counteract the reduced ASL height by rehydrating the mucus in CF, administration of nebulized hypertonic saline (HTS) was proposed. Administration of $7 \%$ HTS increased the mucociliary clearance and lung function and decreased the frequency of exacerbations [241, 242] (Table 2). In cell models hyperosmolarity increases the CXCL8 production by activating the $\mathrm{p} 38$ mitogen-activated protein kinase pathway $[243,244]$. In contrast, in the sputum of CF patients HTS had either no effect $[245,246]$ or decreased CXCL8 levels and reduced the neutrophil chemotactic efficiency [247]. The latter observation is consistent with the HTS-mediated release of glycosaminoglycan bound CXCL8 that promotes its proteolytic cleavage and reduces the half-life and function of CXCL8 as neutrophil chemoattractant [247-249]. This leads to a reduced number of neutrophils in the CF sputum after HTS treatment [246]. A direct role of reduced ASL height in the augmented neutrophil chemotaxis in CF was suggested by a study of WT and $\triangle$ F508-CFTR tracheal epithelial cells [250]. Here, Pseudomonas aeruginosa infection increased the overall apical and basolateral release of the chemokines CXCL1, CXCL2, CXCL5, and CXCL10 to a similar extent in CF and WT epithelial cells. However, when the apical chemokine concentration was adjusted to the reduced ASL volume in $\mathrm{CF}$, a significantly increased concentration gradient across the epithelial monolayer became apparent that 
explains the doubled transmigration of neutrophils across the CF monolayers [250] (Figure 2(a)).

3.2. Bicarbonate Transport. Lack of bicarbonate transport at the apical membrane of epithelia results in reduced $\mathrm{pH}$ of the epithelial lining fluid as indicated by measurements of the ASL, bile, or pancreatic fluid in CF [77, 78, 216, 251-254]. This $\mathrm{pH}$ difference might be attributed to the lack of CFTRmediated bicarbonate transport $[255,256]$ or to the absence of CFTR-mediated regulation of the chloride/bicarbonate exchanger pendrin or other members of the SLC26 family $[159,163,257]$. The $\mathrm{pH}$ difference is augmented by the nongastric $\mathrm{H}^{+} / \mathrm{K}^{+}$adenosine triphosphatase ATP12A activity that in human and pig mediates $\mathrm{H}^{+}$transport into the ASL [258].

Reduced ASL bicarbonate and $\mathrm{pH}$ could provoke $\mathrm{CF}$ and CF-like phenotypes by multiple mechanisms. (i) Mucins packaging in goblet cell granules requires the presence of high intragranular calcium concentrations and acidic $\mathrm{pH}$. Upon exocytosis, calcium chelation by bicarbonate and normal ASL $\mathrm{pH}$ facilitate mucin unfolding, prerequisite for their proteolytic cleavage and release from the cells surface [259, 260]. Impaired mucus detachment in CF pig submucosal glands and attenuated mucus release in CF mouse intestine highlight the importance of this mechanism [261-263]. In addition, the increased viscosity of mucins at acidic $\mathrm{pH}$ could contribute to the mucociliary clearance defect in CF [264]. (ii) Reduced ASL pH attenuates the bactericidal effect of antimicrobial peptides, key components of the innate immune response of the lung. $\mathrm{pH}$-dependent activity was shown for lysozyme, lactoferrin, $\beta$-defensin-3, and LL-37 and a deleterious effect on their synergistic bactericidal properties upon pH-reduction was observed $[78,265]$. (iii) The reduced ASL pH may also directly activate chemokine and cytokine expression and release by activating one or more of the following acid-sensing signaling pathways (Figure 2(b)). (a) Proton-sensing G-protein-coupled receptors, including GPR4, GPR65 (TDAG8), GPR68 (OGR1), and GPR132 $(\mathrm{G} 2 \mathrm{~A})$, regulate the inflammatory response among other functions [266]. Upon activation by acidic pH GPR4 predominantly signals via the $G_{S}$ pathway resulting in activation of cAMP formation $[267,268]$ and increased expression of inflammatory genes including chemokines (CXCL2, CXCL8, and CCL20), cytokines, adhesion molecules, NF- $\kappa$ B pathway genes, and stress response genes [269]. GPR68, which is inactive at $\mathrm{pH} 7.8$ and fully activated at $\mathrm{pH}$ 6.8, mainly acts through $\mathrm{G}_{\mathrm{q}}$ [268]. It is expressed in airway epithelia and stimulates the phospholipase $\mathrm{C}$ activity as well as intracellular $\mathrm{Ca}^{2+}$ signaling and has been implicated in the acid-induced mucin5AC and IL-6 secretion [270, 271]. (b) The activity of the receptor tyrosine kinases ErbB1 and ErbB2 is increased by low extracellular $\mathrm{pH}$ [272], which can contribute to the increase in CXCL8 production [273]. (c) The short palate lung and nasal epithelial clone 1 (SPLUNC1) is a $\mathrm{pH}$-sensitive regulator of $\mathrm{ENaC}$ and is unable to inhibit $\mathrm{ENaC}$ in the acidic CF airway environment [252]. Thus, the ensuing increased $\mathrm{ENaC}$ activity may result in decreased ALS volume [274] that can trigger augmented chemokine signaling as discussed above.
Aberrant mucin release and reduced bactericidal properties of the lining fluid could promote chronic bacterial infection that in concert with augmented chemokine and cytokine secretion would lead to the hyperinflammatory state seen in CF and other diseases. However, CFTR mutants like R75Q which have normal chloride but selective disruption of bicarbonate conductance do not cause classical CF [195] but are associated with recurrent acute and chronic pancreatitis [198].

3.3. Glutathione and Thiocyanate Transport. Another potential mechanism to perpetuate the imbalance in chemokine production in CF and perhaps other inflammatory disorders is oxidative stress arising from oxidant-antioxidant imbalance. Besides transporting chloride and bicarbonate, CFTR may serve as an efflux channel for reduced glutathione (GSH) $[275,276]$ and thiocyanate $[277,278]$. The ASL concentration of GSH was estimated in the $275-430 \mu \mathrm{M}$ range in healthy individuals $[279,280]$. In contrast in CF patients total GSH concentrations are reduced to $92 \mu \mathrm{M}$ but the concentration of the oxidised form (GSSG) was not affected by the absence of CFTR activity, thus shifting the redox potential from $-175 \mathrm{mV}$ to $-128 \mathrm{mV}$ [280]. This shift in redox potential may decrease the redox buffering capacity of the ASL and therefore affect the oxidation state of membrane proteins that could induce downstream proinflammatory signaling [281, 282]. However, it is not well understood how differences in extracellular GSH could result in aberrant gene expression. Increased or insufficiently buffered hydrogen peroxide production at the apical membrane of CF epithelia by NADPH oxidases, especially by the dual oxidase 1 (DUOX1) [283, 284], may increase metalloproteinase-mediated release of ligands that activate the ErbB1 signaling pathway resulting in augmented CXCL8 production [273, 285] (Figure 2(c)). This is consistent with the protective role of extracellular GSH supplementation upon infection with Pseudomonas aeruginosa in CF cells that reduced the release of CXCL8 and IL-6 [97, 286].

Direct GSH supplementation was explored as a therapeutic approach for CF as early as 1985. In this study the authors demonstrated that aerosol administered GSH led to an increase in BAL GSH and GSSG levels and decrease in reactive oxygen species [287]. While this and other initial studies were promising, showing an increase in BAL GSH level and improved lung function [288], the improvement could not be confirmed in a recent phase $2 \mathrm{~b}$ trial [289]. Antioxidant treatment with $\mathrm{N}$-acetylcysteine (NAC) that has a weak antioxidant character but predominantly acts through the replenishment of GSH in deficient cells [290] was explored as alternative to GSH. Initial short-term studies $(\leq 3$ month) did not report a significant improvement in CF lung function [291, 292]. Interestingly, administering high doses of NAC three times daily reduced NE, neutrophil counts, and CXCL8 in the sputum of CF patients [293]. A recent phase 2 trial reports a significant relative increase in $\mathrm{FEV}_{1}$ by $4.4 \%$ after 24 -week treatment, which is predominantly due to stabilization of the lung function in the treatment group while it declined in the control group [294] (Table 2).

Thiocyanate acts both as an antioxidant [295] and precursor for the bactericidal hypothiocyanite [296]. Reduced level 


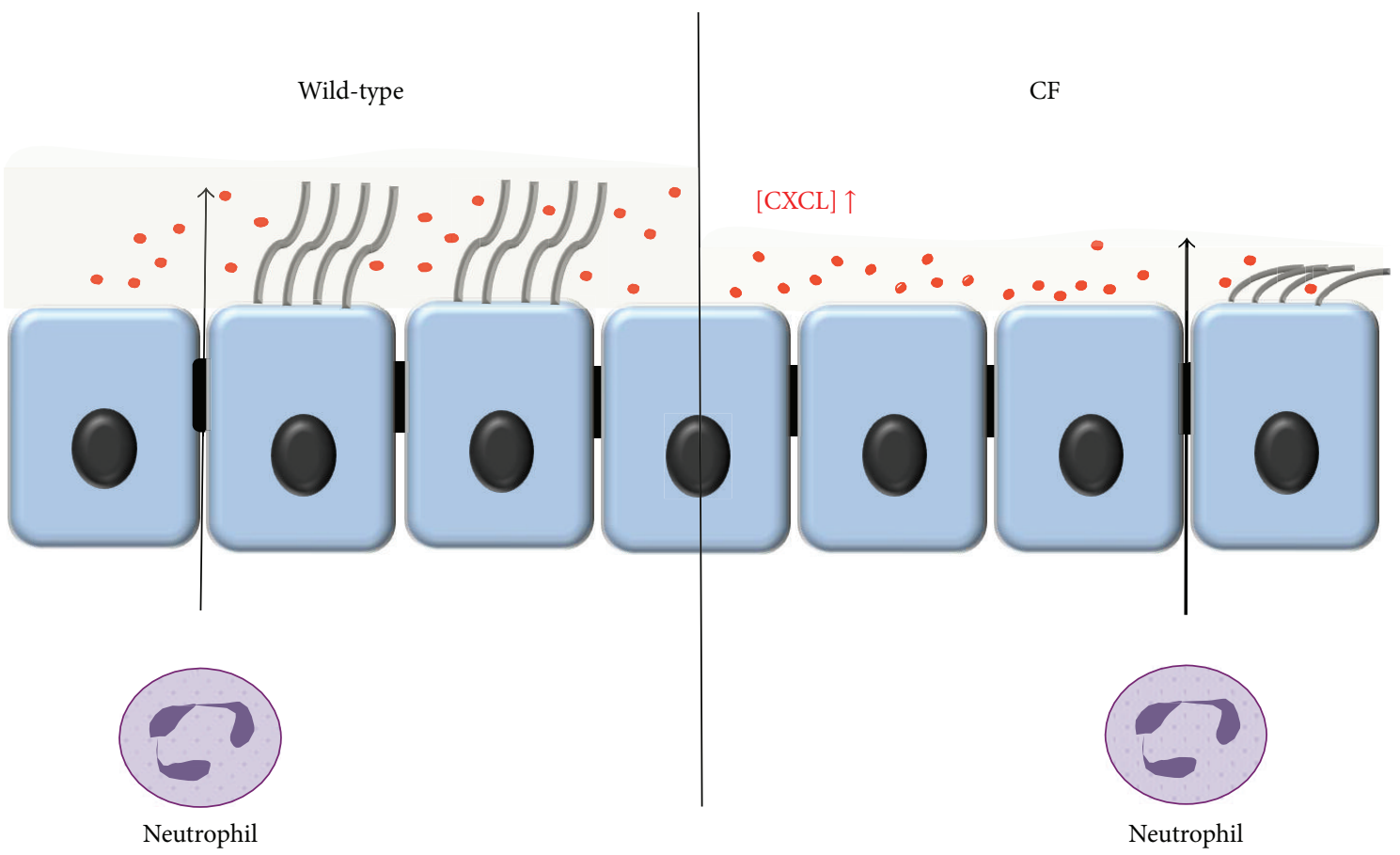

(a)

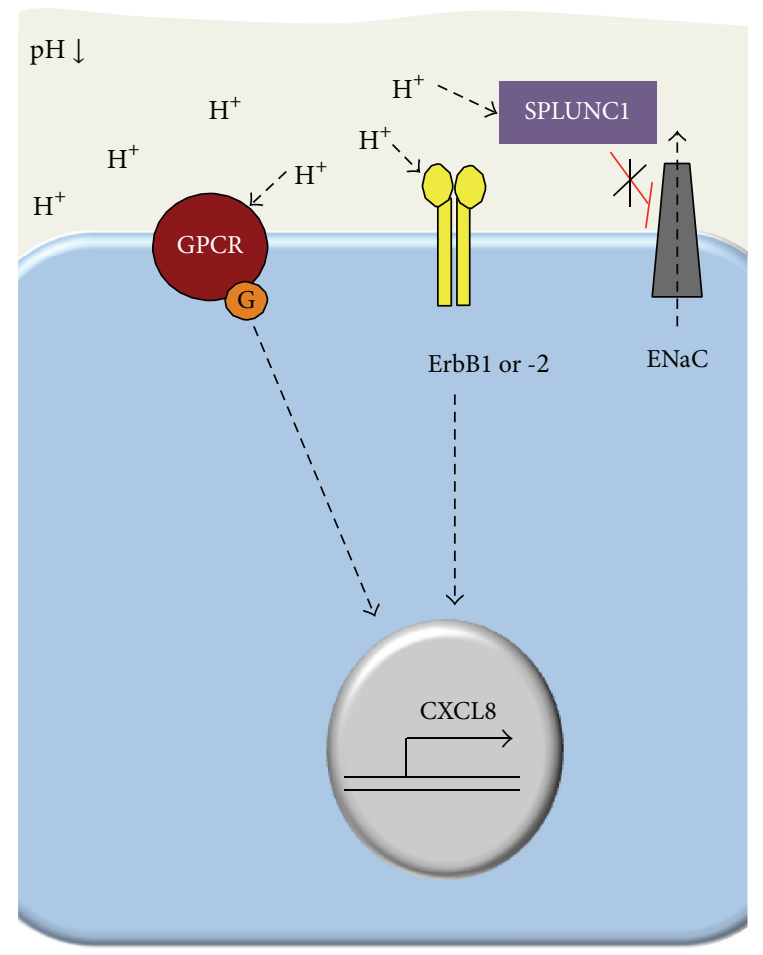

(b)

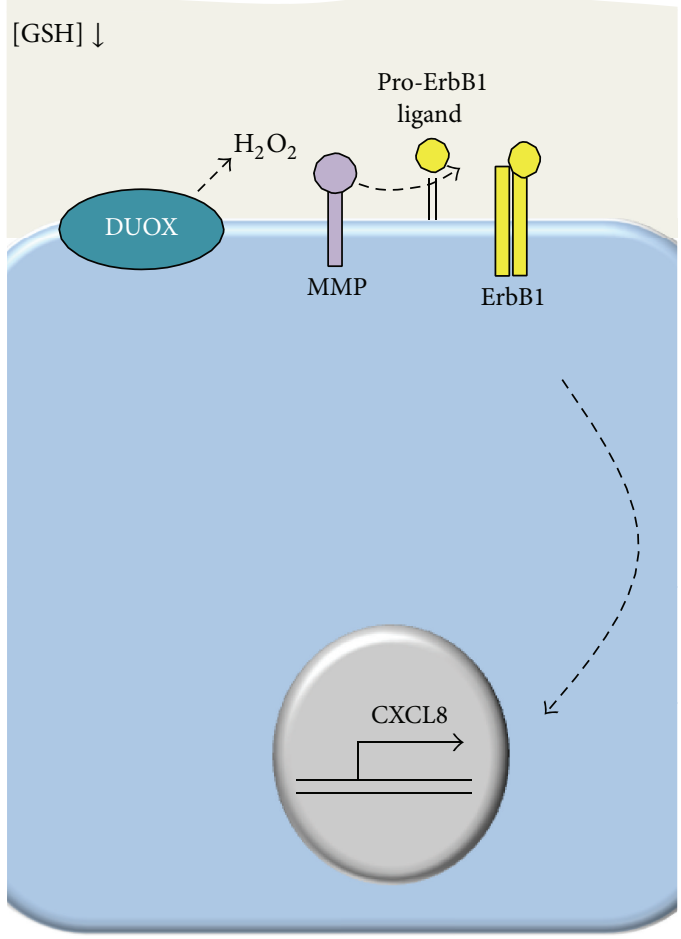

(c)

FIgURE 2: Putative mechanisms linking impaired anion transport to augmented epithelial chemokine signaling in secretory epithelia. (a) Low ASL in CF results in elevated concentrations of CXCL chemokines due to the reduced liquid volume in the luminal compartment. The increased concentration gradient enhances the neutrophil chemotaxis [250]. (b) Low ASL pH may directly activate chemokine expression by activating acid-sensing signaling pathways via proton-sensing GPCRs, ErbB1, and ErbB2 or the soluble protein SPLUNC1. (c) The decreased ROS buffering capacity of the ASL due to the reduced GSH concentration may promote hydrogen peroxide $\left(\mathrm{H}_{2} \mathrm{O}_{2}\right)$ mediated metalloproteinase (MMP) activation. These in turn cleave pro-erbB1 ligands resulting in erbB1 activation, thus initiating signaling pathways that lead to the upregulation of chemokine expression [285]. 
of thiocyanate in the epithelial lining fluid has been observed in CF cells, CF mice [297], and CF patients [298]. Restoring the thiocyanate levels in $\beta$-ENaC overexpressing mice, a model for CF [70], using nebulized thiocyanate decreased the bacterial burden after Pseudomonas aeruginosa infection and attenuated neutrophil infiltration and reduced the levels of the chemokine CXCL1 and cytokines IL- 6 and TNF- $\alpha$ in the BAL [299].

\section{Conclusion}

The discussed mechanisms, linking attenuated anion transport to the inflammatory state in CF and other diseases, are not mutually exclusive. Therefore it is likely that symptomatic correction of any single one of these transport defects will result in only minor benefit. This is evident by the results of the clinical trials using HTS to rehydrate the mucus in CF that resulted in only a modest improvement in lung function [241, 242] and using inhaled GSH to increase the ASL antioxidant level that was not beneficial [289] (Table 2). Recent advances to correct the underlying defect in CF by folding correctors and gating potentiators of CFTR are promising, and drugs targeting a subset of CF-causing mutations are approved [25, 28]. These compounds might be beneficial for other diseases with an acquired loss of CFTR function phenotype like, for example, COPD. Treatment with the gating potentiator ivacaftor increased the WT-CFTR activity in cigarette smoke exposed primary human bronchial epithelia and partially reverted the smoke-induced mucociliary clearance defect [300]. The University of Alabama recently announced a phase I clinical trial with ivacaftor in COPD patients [301]. Considering the limited efficacy of this potentiator to increase the open probability of WT-CFTR [302] and the documented downregulation of CFTR expression in COPD [117, 122], stabilizing the protein with a corrector drug would be another promising strategy.

Alternative ion channels like TMEM16A or SLC26A9 may compensate for CFTR dysfunction [303]. For TMEM16A this was attempted using the stable UTP analog denufosol that stimulates P2Y-receptor-induced cytoplasmic calcium signaling and thus channel activity [304] (Table 2). This approach was unsuccessful [305], likely due to the rapid desensitization and internalization of the P2Y-receptor [67, 306-308]. These limitations could be overcome by the activator $\mathrm{F}$ that probably activates TMEM16A allosterically without triggering cytosolic calcium signaling [309] and that was shown to reduce CXCL8 secretion in a CF cell model [67]. TMEM16A is widely expressed [132], including in the airway smooth muscle where it is implicated in the hyperresponsiveness in asthma $[133,310]$. To target this channel for therapy therefore requires the identification and exploitation of an epithelial cell specific splice isoform [311] or regulatory mechanism.

\section{Competing Interests}

The authors declare that there are no competing interests regarding the publication of this paper.

\section{Acknowledgments}

This work was supported by Cystic Fibrosis Canada, National Institutes of Health (NIH) DK075302, and Canadian Institutes of Health Research (CIHR) to Gergely L. Lukacs as well as the Hungarian Scientific Research Fund K116634 and the Momentum Grant of the Hungarian Academy of Sciences LP2014-10/2014 to Péter Hegyi. Andrea Schnúr was supported in part by postdoctoral fellowship from Cystic Fibrosis Canada and by postdoctoral fellowship of the CIHR-Funded Chemical Biology Training Program. Simon Rousseau acknowledges a salary award from the FRQ-S. Gergely L. Lukacs is recipient of a Canada Research Chair.

\section{References}

[1] R. A. Frizzell and J. W. Hanrahan, "Physiology of epithelial chloride and fluid secretion," Cold Spring Harbor Perspectives in Medicine, vol. 2, no. 6, Article ID a009563, 2012.

[2] M. I. Hollenhorst, K. Richter, and M. Fronius, "Ion transport by pulmonary epithelia," Journal of Biomedicine and Biotechnology, vol. 2011, Article ID 174306, 16 pages, 2011.

[3] J. Shan, J. Huang, J. Liao, R. Robert, and J. W. Hanrahan, "Anion secretion by a model epithelium: more lessons from Calu-3," Acta Physiologica, vol. 202, no. 3, pp. 523-531, 2011.

[4] P. S. Hiemstra, P. B. McCray Jr., and R. Bals, "The innate immune function of airway epithelial cells in inflammatory lung disease," European Respiratory Journal, vol. 45, no. 4, pp. 1150-1162, 2015.

[5] D. E. Davies, "Epithelial barrier function and immunity in asthma," Annals of the American Thoracic Society, vol. 11, pp. S244-S255, 2014.

[6] H. Hammad and B. N. Lambrecht, "Barrier epithelial cells and the control of type 2 immunity," Immunity, vol. 43, no. 1, pp. 2940, 2015.

[7] D. Parker and A. Prince, "Innate immunity in the respiratory epithelium," American Journal of Respiratory Cell and Molecular Biology, vol. 45, no. 2, pp. 189-201, 2011.

[8] F. Stanke, "The contribution of the airway epithelial cell to host defense," Mediators of Inflammation, vol. 2015, Article ID 463016, 7 pages, 2015.

[9] M. Eisenhut and H. Wallace, "Ion channels in inflammation," Pflugers Archiv-European Journal of Physiology, vol. 461, no. 4, pp. 401-421, 2011.

[10] L. J. V. Galietta, C. Folli, E. Caci et al., "Effect of inflammatory stimuli on airway ion transport," Proceedings of the American Thoracic Society, vol. 1, no. 1, pp. 62-65, 2004.

[11] D. M. McKay and A. W. Baird, "Cytokine regulation of epithelial permeability and ion transport," Gut, vol. 44, no. 2, pp. 283-289, 1999.

[12] C. Nofziger, S. Dossena, S. Suzuki, K. Izuhara, and M. Paulmichl, "Pendrin function in airway epithelia," Cellular Physiology and Biochemistry, vol. 28, no. 3, pp. 571-578, 2011.

[13] L. J. V. Galietta, P. Pagesy, C. Folli et al., "IL-4 is a potent modulator of ion transport in the human bronchial epithelium in vitro," The Journal of Immunology, vol. 168, no. 2, pp. 839-845, 2002.

[14] H. Danahay, H. Atherton, G. Jones, R. J. Bridges, and C. T. Poll, "Interleukin-13 induces a hypersecretory ion transport phenotype in human bronchial epithelial cells," American Journal of Physiology_Lung Cellular and Molecular Physiology, vol. 282, no. 2, pp. L226-L236, 2002. 
[15] A. Caputo, E. Caci, L. Ferrera et al., "TMEM16A, a membrane protein associated with calcium-dependent chloride channel activity," Science, vol. 322, no. 5901, pp. 590-594, 2008.

[16] P. Scudieri, E. Caci, S. Bruno et al., "Association of TMEM16A chloride channel overexpression with airway goblet cell metaplasia," Journal of Physiology, vol. 590, no. 23, pp. 6141-6155, 2012.

[17] P. Anagnostopoulou, B. Riederer, J. Duerr et al., "SLC26A9mediated chloride secretion prevents mucus obstruction in airway inflammation," Journal of Clinical Investigation, vol. 122, no. 10, pp. 3629-3634, 2012.

[18] S. Bitam, I. Pranke, M. Hollenhorst et al., "An unexpected effect of TNF- $\alpha$ on F508del-CFTR maturation and function," F1000Research, vol. 4, article 218, 2015.

[19] L. J. V. Galietta, C. Folli, C. Marchetti et al., "Modification of transepithelial ion transport in human cultured bronchial epithelial cells by interferon- $\gamma$," American Journal of Physiology_Lung Cellular and Molecular Physiology, vol. 278, no. 6, pp. L1186-L1194, 2000.

[20] F. Besancon, G. Przewlocki, I. Baro, A. S. Hongre, D. Escande, and A. Edelman, "Interferon-gamma downregulates CFTR gene expression in epithelial cells," American Journal of Physiology, vol. 267, no. 5, pp. C1398-C1404, 1994.

[21] J. Roux, C. M. McNicholas, M. Carles et al., "IL-8 inhibits cAMP-stimulated alveolar epithelial fluid transport via a GRK2/PI3K-dependent mechanism," The FASEB Journal, vol. 27, no. 3, pp. 1095-1106, 2013.

[22] F. S. Collins, "Cystic fibrosis: molecular biology and therapeutic implications," Science, vol. 256, no. 5058, pp. 774-779, 1992.

[23] S. M. Rowe, S. Miller, and E. J. Sorscher, "Cystic fibrosis," The New England Journal of Medicine, vol. 352, no. 19, pp. 1992-2001, 2005.

[24] J. R. Riordan, J. M. Rommens, B.-S. Kerem et al., "Identification of the cystic fibrosis gene: cloning and characterization of complementary DNA," Science, vol. 245, no. 4922, pp. 10661073, 1989.

[25] G. R. Cutting, "Cystic fibrosis genetics: from molecular understanding to clinical application," Nature Reviews Genetics, vol. 16, no. 1, pp. 45-56, 2015.

[26] Cystic Fibrosis Mutation Database, http://www.genet.sickkids .on.ca/app.

[27] P. R. Sosnay, K. R. Siklosi, F. Van Goor et al., "Defining the disease liability of variants in the cystic fibrosis transmembrane conductance regulator gene," Nature Genetics, vol. 45, no. 10, pp. 1160-1167, 2013.

[28] G. Veit, R. G. Avramescu, A. N. Chiang et al., "From CFTR biology toward combinatorial pharmacotherapy: expanded classification of cystic fibrosis mutations," Molecular Biology of the Cell, vol. 27, no. 3, pp. 424-433, 2016.

[29] The Clinical and Functional Translation of CFTR, http://www .cftr2.org/.

[30] M. Wilschanski and I. Novak, "The cystic fibrosis of exocrine pancreas," Cold Spring Harbor Perspectives in Medicine, vol. 3, no. 5, Article ID a009746, 2013.

[31] J. Zielenski, "Genotype and phenotype in cystic fibrosis," Respiration, vol. 67, no. 2, pp. 117-133, 2000.

[32] P. Hegyi, M. Wilschanski, S. Muallem et al., "CFTR: a new horizon in the pathomechanism and treatment of pancreatitis," in Reviews of Physiology, Biochemistry and Pharmacology, vol. 170, pp. 37-66, Springer, 2016.
[33] P. Kristidis, D. Bozon, M. Corey et al., "Genetic determination of exocrine pancreatic function in cystic fibrosis," American Journal of Human Genetics, vol. 50, no. 6, pp. 1178-1184, 1992.

[34] H. Shwachman, E. Lebenthal, and K. T. Khaw, "Recurrent acute pancreatitis in patients with cystic fibrosis with normal pancreatic enzymes," Pediatrics, vol. 55, no. 1, pp. 86-95, 1975.

[35] K. De Boeck, M. Weren, M. Proesmans, and E. Kerem, "Pancreatitis among patients with cystic fibrosis: correlation with pancreatic status and genotype," Pediatrics, vol. 115, no. 4, pp. e463-e469, 2005.

[36] H. Matsui, B. R. Grubb, R. Tarran et al., "Evidence for periciliary liquid layer depletion, not abnormal ion composition, in the pathogenesis of cystic fibrosis airways disease," Cell, vol. 95, no. 7, pp. 1005-1015, 1998.

[37] R. Tarran, B. R. Grubb, D. Parsons et al., "The CF salt controversy: in vivo observations and therapeutic approaches," Molecular Cell, vol. 8, no. 1, pp. 149-158, 2001.

[38] N. Derichs, B.-J. Jin, Y. Song, W. E. Finkbeiner, and A. S. Verkman, "Hyperviscous airway periciliary and mucous liquid layers in cystic fibrosis measured by confocal fluorescence photobleaching," FASEB Journal, vol. 25, no. 7, pp. 2325-2332, 2011.

[39] D. A. Stoltz, D. K. Meyerholz, and M. J. Welsh, "Origins of cystic fibrosis lung disease," The New England journal of medicine, vol. 372, no. 4, pp. 351-362, 2015.

[40] D. G. Downey, S. C. Bell, and J. S. Elborn, "Neutrophils in cystic fibrosis," Thorax, vol. 64, no. 1, pp. 81-88, 2009.

[41] J. Laval, A. Ralhan, and D. Hartl, "Neutrophils in cystic fibrosis," Biological Chemistry, vol. 397, no. 6, 2016.

[42] D. P. Nichols and J. F. Chmiel, "Inflammation and its genesis in cystic fibrosis," Pediatric Pulmonology, vol. 50, supplement 40, pp. S39-S56, 2015.

[43] M. S. Twigg, S. Brockbank, P. Lowry, S. P. Fitzgerald, C. Taggart, and S. Weldon, "The role of serine proteases and antiproteases in the cystic fibrosis lung," Mediators of Inflammation, vol. 2015, Article ID 293053, 10 pages, 2015.

[44] P. Birrer, N. G. Mcelvaney, A. Rüdeberg et al., "Proteaseantiprotease imbalance in the lungs of children with cystic fibrosis," American Journal of Respiratory and Critical Care Medicine, vol. 150, no. 1, pp. 207-213, 1994.

[45] J. M. Devaney, C. M. Greene, C. C. Taggart, T. P. Carroll, S. J. O'Neill, and N. G. McElvaney, "Neutrophil elastase up-regulates interleukin-8 via toll-like receptor 4," FEBS Letters, vol. 544, no. 1-3, pp. 129-132, 2003.

[46] H. Nakamura, K. Yoshimura, N. G. McElvaney, and R. G. Crystal, "Neutrophil elastase in respiratory epithelial lining fluid of individuals with cystic fibrosis induces interleukin8 gene expression in a human bronchial epithelial cell line," Journal of Clinical Investigation, vol. 89, no. 5, pp. 1478-1484, 1992.

[47] M. X. G. Shao and J. A. Nadel, "Neutrophil elastase induces MUC5AC mucin production in human airway epithelial cells via a cascade involving protein kinase $C$, reactive oxygen species, and TNF- $\alpha$-converting enzyme," Journal of Immunology, vol. 175, no. 6, pp. 4009-4016, 2005.

[48] J.-A. Park, F. He, L. D. Martin, Y. Li, B. N. Chorley, and K. B. Adler, "Human neutrophil elastase induces hypersecretion of mucin from well-differentiated human bronchial epithelial cells in vitro via a protein kinase $C \delta$-mediated mechanism," American Journal of Pathology, vol. 167, no. 3, pp. 651-661, 2005. 
[49] S. Weldon, P. McNally, N. G. McElvaney et al., "Decreased levels of secretory leucoprotease inhibitor in the Pseudomonasinfected cystic fibrosis lung are due to neutrophil elastase degradation," The Journal of Immunology, vol. 183, no. 12, pp. 8148-8156, 2009.

[50] M. Le Gars, D. Descamps, D. Roussel et al., "Neutrophil elastase degrades cystic fibrosis transmembrane conductance regulator via calpains and disables channel function in vitro and in vivo," American Journal of Respiratory and Critical Care Medicine, vol. 187, no. 2, pp. 170-179, 2013.

[51] E. Hayes, K. Pohl, N. G. McElvaney, and E. P. Reeves, "The cystic fibrosis neutrophil: a specialized yet potentially defective cell," Archivum Immunologiae et Therapiae Experimentalis, vol. 59, no. 2, pp. 97-112, 2011.

[52] K. Pohl, E. Hayes, J. Keenan et al., "A neutrophil intrinsic impairment affecting Rab27a and degranulation in cystic fibrosis is corrected by CFTR potentiator therapy," Blood, vol. 124, no. 7, pp. 999-1009, 2014.

[53] R. G. Painter, V. G. Valentine, N. A. Lanson Jr. et al., "CFTR expression in human neutrophils and the phagolysosomal chlorination defect in cystic fibrosis," Biochemistry, vol. 45, no. 34, pp. 10260-10269, 2006.

[54] R. G. Painter, L. Marrero, G. A. Lombard, V. G. Valentine, W. M. Nauseef, and G. Wang, "CFTR-mediated halide transport in phagosomes of human neutrophils," Journal of Leukocyte Biology, vol. 87, no. 5, pp. 933-942, 2010.

[55] T. E. Machen, "Innate immune response in CF airway epithelia: hyperinflammatory?" American Journal of Physiology-Cell Physiology, vol. 291, no. 2, pp. C218-C230, 2006.

[56] A. Elizur, C. L. Cannon, and T. W. Ferkol, "Airway inflammation in cystic fibrosis," Chest, vol. 133, no. 2, pp. 489-495, 2008.

[57] M. Cohen-Cymberknoh, E. Kerem, T. Ferkol, and A. Elizur, "Airway inflammation in cystic fibrosis: molecular mechanisms and clinical implications," Thorax, vol. 68, no. 12, pp. 1157-1162, 2013.

[58] R. Ratcliff, M. J. Evans, A. W. Cuthbert et al., "Production of a severe cystic fibrosis mutation in mice by gene targeting," Nature Genetics, vol. 4, no. 1, pp. 35-41, 1993.

[59] J. N. Snouwaert, K. K. Brigman, A. M. Latour et al., "An animal model for cystic fibrosis made by gene targeting," Science, vol. 257, no. 5073, pp. 1083-1088, 1992.

[60] S. J. Delaney, E. W. F. W. Alton, S. N. Smith et al., "Cystic fibrosis mice carrying the missense mutation G551D replicate human genotype-phenotype correlations," The EMBO Journal, vol. 15, no. 5, pp. 955-963, 1996.

[61] J. H. van Doorninck, P. J. French, E. Verbeek et al., "A mouse model for the cystic fibrosis $\triangle \mathrm{F} 508$ mutation," The EMBO Journal, vol. 14, no. 18, pp. 4403-4411, 1995.

[62] W. H. Colledge, B. S. Abella, K. W. Southern et al., "Generation and characterization of a $\Delta$ F508 cystic fibrosis mouse model," Nature Genetics, vol. 10, no. 4, pp. 445-452, 1995.

[63] X. Gavilanes, F. Huaux, M. Meyer et al., "Azithromycin fails to reduce increased expression of neutrophil-related cytokines in primary-cultured epithelial cells from cystic fibrosis mice," Journal of Cystic Fibrosis, vol. 8, no. 3, pp. 203-210, 2009.

[64] A. Van Heeckeren, R. Walenga, M. W. Konstan, T. Bonfield, P. B. Davis, and T. Ferkol, "Excessive inflammatory response of cystic fibrosis mice to bronchopulmonary infection with Pseudomonas aeruginosa," Journal of Clinical Investigation, vol. 100, no. 11, pp. 2810-2815, 1997.
[65] J. Dalli, G. Rosignoli, R. P. G. Hayhoe, A. Edelman, and M. Perretti, "CFTR inhibition provokes an inflammatory response associated with an imbalance of the annexin A1 pathway," American Journal of Pathology, vol. 177, no. 1, pp. 176-186, 2010.

[66] M. Kelly, S. Trudel, F. Brouillard et al., "Cystic fibrosis transmembrane regulator inhibitors CFTRinh-172 and GlyH-101 target mitochondrial functions, independently of chloride channel inhibition," Journal of Pharmacology and Experimental Therapeutics, vol. 333, no. 1, pp. 60-69, 2010.

[67] G. Veit, F. Bossard, J. Goepp et al., "Proinflammatory cytokine secretion is suppressed by TMEM16A or CFTR channel activity in human cystic fibrosis bronchial epithelia," Molecular Biology of the Cell, vol. 23, no. 21, pp. 4188-4202, 2012.

[68] N. Melis, M. Tauc, M. Cougnon et al., "Revisiting CFTR inhibition: a comparative study of CFTRinh-172 and GlyH-101 inhibitors," British Journal of Pharmacology, vol. 171, no. 15, pp. 3716-3727, 2014.

[69] M. J. Stutts, C. M. Canessa, J. C. Olsen et al., "CFTR as a cAMPdependent regulator of sodium channels," Science, vol. 269, no. 5225, pp. 847-850, 1995.

[70] M. Mall, B. R. Grubb, J. R. Harkema, W. K. O’Neal, and R. C. Boucher, "Increased airway epithelial $\mathrm{Na}+$ absorption produces cystic fibrosis-like lung disease in mice," Nature Medicine, vol. 10, no. 5, pp. 487-493, 2004.

[71] K. L. Tuggle, S. E. Birket, X. Cui et al., "Characterization of defects in ion transport and tissue development in Cystic Fibrosis Transmembrane Conductance Regulator (CFTR)-knockout rats," PLoS ONE, vol. 9, no. 3, Article ID e91253, 2014.

[72] C. S. Rogers, Y. Hao, T. Rokhlina et al., "Production of CFTRnull and CFTR- $\Delta$ F508 heterozygous pigs by adeno-associated virus-mediated gene targeting and somatic cell nuclear transfer," The Journal of Clinical Investigation, vol. 118, no. 4, pp. 15711577, 2008.

[73] X. Sun, Z. Yan, Y. Yi et al., "Adeno-associated virus-targeted disruption of the CFTR gene in cloned ferrets," Journal of Clinical Investigation, vol. 118, no. 4, pp. 1578-1583, 2008.

[74] C. S. Rogers, D. A. Stoltz, D. K. Meyerholz et al., "Disruption of the CFTR gene produces a model of cystic fibrosis in newborn pigs," Science, vol. 321, no. 5897, pp. 1837-1841, 2008.

[75] X. Sun, H. Sui, J. T. Fisher et al., "Disease phenotype of a ferret CFTR-knockout model of cystic fibrosis," Journal of Clinical Investigation, vol. 120, no. 9, pp. 3149-3160, 2010.

[76] L. S. Ostedgaard, D. K. Meyerholz, J. Chen et al., "The $\Delta F 508$ mutation causes CFTR misprocessing and cystic fibrosis-like disease in pigs," Science Translational Medicine, vol. 3, no. 74, Article ID 74ra24, 2011.

[77] N. W. Keiser, S. E. Birket, I. A. Evans et al., "Defective innate immunity and hyperinflammation in newborn cystic fibrosis transmembrane conductance regulator-knockout ferret lungs," American Journal of Respiratory Cell and Molecular Biology, vol. 52, no. 6, pp. 683-694, 2015.

[78] A. A. Pezzulo, X. X. Tang, M. J. Hoegger et al., "Reduced airway surface $\mathrm{pH}$ impairs bacterial killing in the porcine cystic fibrosis lung," Nature, vol. 486, no. 7405, pp. 109-113, 2012.

[79] M. Abu-El-Haija, M. Sinkora, D. K. Meyerholz et al., "An activated immune and inflammatory response targets the pancreas of newborn pigs with cystic fibrosis," Pancreatology, vol. 11, no. 5, pp. 506-515, 2011.

[80] A. Navis and M. Bagnat, "Loss of cftr function leads to pancreatic destruction in larval zebrafish," Developmental Biology, vol. 399, no. 2, pp. 237-248, 2015. 
[81] T. Z. Khan, J. S. Wagener, T. Bost, J. Martinez, F. J. Accurso, and D. W. H. Riches, "Early pulmonary inflammation in infants with cystic fibrosis," American Journal of Respiratory and Critical Care Medicine, vol. 151, no. 4, pp. 1075-1082, 1995.

[82] T. L. Noah, H. R. Black, P.-W. Cheng, R. E. Wood, and M. W. Leigh, "Nasal and bronchoalveolar lavage fluid cytokines in early cystic fibrosis," Journal of Infectious Diseases, vol. 175, no. 3, pp. 638-647, 1997.

[83] M. S. Muhlebach, P. W. Stewart, M. W. Leigh, and T. L. Noah, "Quantitation of inflammatory responses to bacteria in young cystic fibrosis and control patients," American Journal of Respiratory and Critical Care Medicine, vol. 160, no. 1, pp. 186191, 1999.

[84] D. S. Armstrong, S. M. Hook, K. M. Jamsen et al., "Lower airway inflammation in infants with cystic fibrosis detected by newborn screening," Pediatric Pulmonology, vol. 40, no. 6, pp. 500-510, 2005.

[85] K. Balough, M. McCubbin, M. Weinberger, W. Smits, R. Ahrens, and R. Fick, "The relationship between infection and inflammation in the early stages of lung disease from cystic fibrosis," Pediatric Pulmonology, vol. 20, no. 2, pp. 63-70, 1995.

[86] D. Y. Koller, I. Nething, J. Otto, R. Urbanek, and I. Eichler, "Cytokine concentrations in sputum from patients with cystic fibrosis and their relation to eosinophil activity," American Journal of Respiratory and Critical Care Medicine, vol. 155, no. 3, pp. 1050-1054, 1997.

[87] T. L. Bonfield, J. R. Panuska, M. W. Konstan et al., "Inflammatory cytokines in cystic fibrosis lungs," American Journal of Respiratory and Critical Care Medicine, vol. 152, no. 6, part 1, pp. 2111-2118, 1995.

[88] C. Moser, P. Ø. Jensen, T. Pressler et al., "Serum concentrations of GM-CSF and G-CSF correlate with the Th1/Th2 cytokine response in cystic fibrosis patients with chronic Pseudomonas aeruginosa lung infection," APMIS, vol. 113, no. 6, pp. 400-409, 2005.

[89] L. Roussel, R. Farias, and S. Rousseau, "IL-33 is expressed in epithelia from patients with cystic fibrosis and potentiates neutrophil recruitment," Journal of Allergy and Clinical Immunology, vol. 131, no. 3, pp. 913-916, 2013.

[90] K. Tiringer, A. Treis, S. Kanolzer et al., "Differential expression of IL-33 and HMGB1 in the lungs of stable cystic fibrosis patients," European Respiratory Journal, vol. 44, no. 3, pp. 802805, 2014.

[91] A. Hector, C. Kröner, M. Carevic et al., "The chemokine CCL18 characterises Pseudomonas infections in cystic fibrosis lung disease," European Respiratory Journal, vol. 44, no. 6, pp. 16081615, 2014.

[92] A. K. Dosanjh, D. Elashoff, and R. C. Robbins, "The bronchoalveolar lavage fluid of cystic fibrosis lung transplant recipients demonstrates increased interleukin- 8 and elastase and decreased IL-10," Journal of Interferon and Cytokine Research, vol. 18, no. 10, pp. 851-854, 1998.

[93] T. L. Bonfield, M. W. Konstan, P. Burfeind, J. R. Panuska, J. B. Hilliard, and M. Berger, "Normal bronchial epithelial cells constitutively produce the anti-inflammatory cytokine interleukin10, which is downregulated in cystic fibrosis," American Journal of Respiratory Cell and Molecular Biology, vol. 13, no. 3, pp. 257261, 1995.

[94] R. Tirouvanziam, S. De Bentzmann, C. Hubeau et al., "Inflammation and infection in naive human cystic fibrosis airway grafts," American Journal of Respiratory Cell and Molecular Biology, vol. 23, no. 2, pp. 121-127, 2000.
[95] R. Tirouvanziam, I. Khazaal, and B. Péault, "Primary inflammation in human cystic fibrosis small airways," American Journal of Physiology - Lung Cellular and Molecular Physiology, vol. 283, no. 2, pp. L445-L451, 2002.

[96] C. M. P. Ribeiro, A. M. Paradiso, U. Schwab et al., "Chronic airway infection/inflammation induces a $\mathrm{Ca}^{2+}{ }_{i}$-dependent hyperinflammatory response in human cystic fibrosis airway epithelia," The Journal of Biological Chemistry, vol. 280, no. 18, pp. 17798-17806, 2005.

[97] L. Roussel, G. Martel, J. Bérubé, and S. Rousseau, “P. aeruginosa drives CXCL8 synthesis via redundant toll-like receptors and NADPH oxidase in CFTR $\triangle$ F508 airway epithelial cells," Journal of Cystic Fibrosis, vol. 10, no. 2, pp. 107-113, 2011.

[98] R. W. Vandivier, T. R. Richens, S. A. Horstmann et al., "Dysfunctional cystic fibrosis transmembrane conductance regulator inhibits phagocytosis of apoptotic cells with proinflammatory consequences," American Journal of Physiology_Lung Cellular and Molecular Physiology, vol. 297, no. 4, pp. L677-L686, 2009.

[99] M. L. Fulcher, S. E. Gabriel, J. C. Olsen et al., "Novel human bronchial epithelial cell lines for cystic fibrosis research," American Journal of Physiology - Lung Cellular and Molecular Physiology, vol. 296, no. 1, pp. L82-L91, 2009.

[100] K. Hybiske, Z. Fu, C. Schwarzer et al., "Effects of cystic fibrosis transmembrane conductance regulator and $\triangle \mathrm{F} 508 \mathrm{CFTR}$ on inflammatory response, ER stress, and $\mathrm{Ca}^{2+}$ of airway epithelia," American Journal of Physiology-Lung Cellular and Molecular Physiology, vol. 293, no. 5, pp. L1250-L1260, 2007.

[101] L. Pizurki, M. A. Morris, M. Chanson et al., "Cystic fibrosis transmembrane conductance regulator does not affect neutrophil migration across cystic fibrosis airway epithelial monolayers," The American Journal of Pathology, vol. 156, no. 4, pp. 1407-1416, 2000.

[102] G. John, S. Chillappagari, B. K. Rubin, D. C. Gruenert, and M. O. Henke, "Reduced surface toll-like receptor-4 expression and absent interferon- $\gamma$-inducible protein-10 induction in cystic fibrosis airway cells," Experimental Lung Research, vol. 37, no. 6, pp. 319-326, 2011.

[103] G. John, A. Ö. Yildirim, B. K. Rubin, D. C. Gruenert, and M. O. Henke, "TLR-4-mediated innate immunity is reduced in cystic fibrosis airway cells," American Journal of Respiratory Cell and Molecular Biology, vol. 42, no. 4, pp. 424-431, 2010.

[104] C. Brigati, B. Banelli, A. di Vinci et al., "Inflammation,HIF-1,and the epigenetics that follows," Mediators of Inflammation, vol. 2010, Article ID 263914, 5 pages, 2010.

[105] A. Perez, A. C. Issler, C. U. Cotton, T. J. Kelley, A. S. Verkman, and P. B. Davis, "CFTR inhibition mimics the cystic fibrosis inflammatory profile," American Journal of Physiology-Lung Cellular and Molecular Physiology, vol. 292, no. 2, pp. L383L395, 2007.

[106] K. S. Crites, G. Morin, V. Orlando et al., "CFTR Knockdown induces proinflammatory changes in intestinal epithelial cells," Journal of Inflammation, vol. 12, article 62, 2015.

[107] J. Bellec, M. Bacchetta, D. Losa, I. Anegon, M. Chanson, and T. H. Nguyen, "CFTR inactivation by lentiviral vector-mediated RNA interference and CRISPR-Cas9 genome editing in human airway epithelial cells," Current Gene Therapy, vol. 15, no. 5, pp. 447-459, 2015.

[108] J. Vestbo, S. S. Hurd, A. G. Agustí et al., "Global strategy for the diagnosis, management, and prevention of chronic obstructive pulmonary disease: GOLD executive summary," American Journal of Respiratory and Critical Care Medicine, vol. 187, no. 4, pp. 347-365, 2013. 
[109] P. J. Barnes, "Cellular and molecular mechanisms of chronic obstructive pulmonary disease," Clinics in Chest Medicine, vol. 35, no. 1, pp. 71-86, 2014.

[110] M. L. Brantly, L. D. Paul, B. H. Miller, R. T. Falk, M. Wu, and R. G. Crystal, "Clinical features and history of the destructive lung disease associated with alpha-1-antitrypsin deficiency of adults with pulmonary symptoms," American Review of Respiratory Disease, vol. 138, no. 2, pp. 327-336, 1988.

[111] http://www.who.int/respiratory/copd/en/.

[112] P. Glader, K. von Wachenfeldt, and C.-G. Löfdahl, "Systemic CD4+ T-cell activation is correlated with FEV1 in smokers," Respiratory Medicine, vol. 100, no. 6, pp. 1088-1093, 2006.

[113] T. C. O'Shaughnessy, T. W. Ansari, N. C. Barnes, and P. K. Jeffery, "Inflammation in bronchial biopsies of subjects with chronic bronchitis: Inverse relationship of $\mathrm{CD}^{+} \mathrm{T}$ lymphocytes with FEV1," American Journal of Respiratory and Critical Care Medicine, vol. 155, no. 3, pp. 852-857, 1997.

[114] M. Saetta, S. Baraldo, L. Corbino et al., "CD8+ve cells in the lungs of smokers with chronic obstructive pulmonary disease," American Journal of Respiratory and Critical Care Medicine, vol. 160, no. 2, pp. 711-717, 1999.

[115] G. Chrysofakis, N. Tzanakis, D. Kyriakoy et al., "Perforin expression and cytotoxic activity of sputum $\mathrm{CD} 8^{+}$lymphocytes in patients with COPD," Chest, vol. 125, no. 1, pp. 71-76, 2004.

[116] J. Majo, H. Ghezzo, and M. G. Cosio, "Lymphocyte population and apoptosis in the lungs of smokers and their relation to emphysema," European Respiratory Journal, vol. 17, no. 5, pp. 946-953, 2001.

[117] M. Bodas, T. Min, S. Mazur, and N. Vij, "Critical modifier role of membrane-cystic fibrosis transmembrane conductance regulator-dependent ceramide signaling in lung injury and emphysema," Journal of Immunology, vol. 186, no. 1, pp. 602613, 2011.

[118] M. T. Dransfield, A. M. Wilhelm, B. Flanagan et al., "Acquired cystic fibrosis transmembrane conductance regulator dysfunction in the lower airways in COPD," Chest, vol. 144, no. 2, pp. 498-506, 2013.

[119] A. M. Cantin, J. W. Hanrahan, G. Bilodeau et al., "Cystic fibrosis transmembrane conductance regulator function is suppressed in cigarette smokers," American Journal of Respiratory and Critical Care Medicine, vol. 173, no. 10, pp. 1139-1144, 2006.

[120] A. Rab, S. M. Rowe, S. V. Raju, Z. Bebok, S. Matalon, and J. F. Collawn, "Cigarette smoke and CFTR: implications in the pathogenesis of COPD," American Journal of Physiology - Lung Cellular and Molecular Physiology, vol. 305, no. 8, pp. L530L541, 2013.

[121] J. E. Rasmussen, J. T. Sheridan, W. Polk, C. M. Davies, and R. Tarran, "Cigarette smoke-induced $\mathrm{Ca}^{2+}$ release leads to cystic fibrosis transmembrane conductance regulator (CFTR) dysfunction," Journal of Biological Chemistry, vol. 289, no. 11, pp. 7671-7681, 2014.

[122] L. A. Clunes, C. M. Davies, R. D. Coakley et al., "Cigarette smoke exposure induces CFTR internalization and insolubility, leading to airway surface liquid dehydration," The FASEB Journal, vol. 26, no. 2, pp. 533-545, 2012.

[123] M. Bodas, T. Min, and N. Vij, "Critical role of CFTR-dependent lipid rafts in cigarette smoke-induced lung epithelial injury," American Journal of Physiology -Lung Cellular and Molecular Physiology, vol. 300, no. 6, pp. L811-L820, 2011.

[124] N. Moretto, S. Bertolini, C. Iadicicco et al., "Cigarette smoke and its component acrolein augment IL-8/CXCL8 mRNA stability via p38 MAPK/MK2 signaling in human pulmonary cells," American Journal of Physiology-Lung Cellular and Molecular Physiology, vol. 303, no. 10, pp. L929-L938, 2012.

[125] L. Llinàs, V. I. Peinado, J. Ramon Goñi et al., "Similar gene expression profiles in smokers and patients with moderate COPD," Pulmonary Pharmacology \& Therapeutics, vol. 24, no. 1, pp. 32-41, 2011.

[126] D. D. Sin, B. E. Miller, A. Duvoix et al., "Serum PARC/CCL-18 concentrations and health outcomes in chronic obstructive pulmonary disease," American Journal of Respiratory and Critical Care Medicine, vol. 183, no. 9, pp. 1187-1192, 2011.

[127] C. Pepe, S. Foley, J. Shannon et al., "Differences in airway remodeling between subjects with severe and moderate asthma," Journal of Allergy and Clinical Immunology, vol. 116, no. 3, pp. 544-549, 2005.

[128] C. H. Fanta, “Asthma," The New England Journal of Medicine, vol. 360, no. 10, pp. 1002-1014, 2009.

[129] A. T. Hastie, W. C. Moore, D. A. Meyers et al., "Analyses of asthma severity phenotypes and inflammatory proteins in subjects stratified by sputum granulocytes," Journal of Allergy and Clinical Immunology, vol. 125, no. 5, pp. 1028-1036.e13, 2010.

[130] S. Robins, L. Roussel, A. Schachter et al., "Steroid-insensitive ERK1/2 activity drives CXCL8 synthesis and neutrophilia by airway smooth muscle," American Journal of Respiratory Cell and Molecular Biology, vol. 45, no. 5, pp. 984-990, 2011.

[131] D. P. Cook, M. V. Rector, D. C. Bouzek et al., "Cystic Fibrosis Transmembrane Conductance Regulator in sarcoplasmic reticulum of airway smooth muscle. Implications for airway contractility," American Journal of Respiratory and Critical Care Medicine, vol. 193, no. 4, pp. 417-426, 2016.

[132] F. Huang, J. R. Rock, B. D. Harfe et al., "Studies on expression and function of the TMEM16A calcium-activated chloride channel," Proceedings of the National Academy of Sciences of the United States of America, vol. 106, no. 50, pp. 21413-21418, 2009.

[133] C.-H. Zhang, Y. Li, W. Zhao et al., "The transmembrane protein $16 \mathrm{~A} \mathrm{Ca}^{2+}$-activated $\mathrm{Cl}^{-}$channel in airway smooth muscle contributes to airway hyperresponsiveness," American Journal of Respiratory and Critical Care Medicine, vol. 187, no. 4, pp. 374381, 2013.

[134] S. McCuaig and J. G. Martin, "How the airway smooth muscle in cystic fibrosis reacts in proinflammatory conditions: Implications for airway hyper-responsiveness and asthma in cystic fibrosis," The Lancet Respiratory Medicine, vol. 1, no. 2, pp. 137147, 2013.

[135] M. Loxham, D. E. Davies, and C. Blume, "Epithelial function and dysfunction in asthma," Clinical and Experimental Allergy, vol. 44, no. 11, pp. 1299-1313, 2014.

[136] T. Aikawa, S. Shimura, H. Sasaki, M. Ebina, and T. Takishima, "Marked goblet cell hyperplasia with mucus accumulation in the airways of patients who died of severe acute asthma attack," Chest, vol. 101, no. 4, pp. 916-921, 1992.

[137] L. M. Kuyper, P. D. Paré, J. C. Hogg et al., "Characterization of airway plugging in fatal asthma," American Journal of Medicine, vol. 115, no. 1, pp. 6-11, 2003.

[138] B. K. Rubin, K. N. Priftis, H. J. Schmidt, and M. O. Henke, "Secretory hyperresponsiveness and pulmonary mucus hypersecretion," Chest, vol. 146, no. 2, pp. 496-507, 2014.

[139] M. A. Hardyman, E. Wilkinson, E. Martin et al., "TNF$\alpha$-mediated bronchial barrier disruption and regulation by src-family kinase activation," Journal of Allergy and Clinical Immunology, vol. 132, no. 3, pp. 665.e8-675.e8, 2013. 
[140] C. Xiao, S. M. Puddicombe, S. Field et al., "Defective epithelial barrier function in asthma," The Journal of Allergy and Clinical Immunology, vol. 128, no. 3, pp. 549-556.e1-12, 2011.

[141] R. J. Freishtat, A. M. Watson, A. S. Benton et al., "Asthmatic airway epithelium is intrinsically inflammatory and mitotically dyssynchronous," American Journal of Respiratory Cell and Molecular Biology, vol. 44, no. 6, pp. 863-869, 2011.

[142] T.-L. Hackett, G. K. Singhera, F. Shaheen et al., "Intrinsic phenotypic differences of asthmatic epithelium and its inflammatory responses to respiratory syncytial virus and air pollution," American Journal of Respiratory Cell and Molecular Biology, vol. 45, no. 5, pp. 1090-1100, 2011.

[143] D. S. Robinson, Q. Hamid, S. Ying et al., "Predominant TH2-like bronchoalveolar T-lymphocyte population in atopic asthma," The New England Journal of Medicine, vol. 326, no. 5, pp. 298304, 1992.

[144] D. M. A. Bullens, E. Truyen, L. Coteur et al., "IL-17 mRNA in sputum of asthmatic patients: linking T cell driven inflammation and granulocytic influx?" Respiratory Research, vol. 7, article 135, 2006.

[145] I. Vachier, C. Bonnans, C. Chavis et al., "Severe asthma is associated with a loss of LX4, an endogenous anti-inflammatory compound," Journal of Allergy and Clinical Immunology, vol. 115, no. 1, pp. 55-60, 2005.

[146] G. Yu and B. Björkstén, "Polyunsaturated fatty acids in school children in relation to allergy and serum IgE levels," Pediatric Allergy and Immunology, vol. 9, no. 3, pp. 133-138, 1998.

[147] C. Kanagaratham, A. Kalivodová, L. Najdekr et al., "Fenretinide prevents inflammation and airway hyperresponsiveness in a mouse model of allergic asthma," American Journal of Respiratory Cell and Molecular Biology, vol. 51, no. 6, pp. 783-792, 2014.

[148] S. D. Freedman, P. G. Blanco, M. M. Zaman et al., "Association of cystic fibrosis with abnormalities in fatty acid metabolism," The New England Journal of Medicine, vol. 350, no. 6, pp. 560-569, 2004.

[149] C. Guilbault, J. B. De Sanctis, G. Wojewodka et al., "Fenretinide corrects newly found ceramide deficiency in cystic fibrosis," American Journal of Respiratory Cell and Molecular Biology, vol. 38, no. 1, pp. 47-56, 2008.

[150] J. L. Colombo, "Long-acting bronchodilators in cystic fibrosis," Current Opinion in Pulmonary Medicine, vol. 9, no. 6, pp. 504508, 2003.

[151] I. Sanchez, R. E. Powell, and H. Pasterkamp, "Wheezing and airflow obstruction during methacholine challenge in children with cystic fibrosis and in normal children," American Review of Respiratory Disease, vol. 147, no. 3, pp. 705-709, 1993.

[152] E. H. J. van Haren, J.-W. J. Lammers, J. Festen, and C. L. A. Van Herwaarden, "Bronchial vagal tone and responsiveness to histamine, exercise and bronchodilators in adult patients with cystic fibrosis," European Respiratory Journal, vol. 5, no. 9, pp. 1083-1088, 1992.

[153] M. Weinberger, "Airways reactivity in patients with CF," Clinical Reviews in Allergy and Immunology, vol. 23, no. 1, pp. 77-85, 2002.

[154] I. M. Balfour-Lynn and J. S. Elborn, "'CF asthma': what is it and what do we do about it?" Thorax, vol. 57, no. 8, pp. 742-748, 2002.

[155] B. D. Kent, S. J. Lane, E. J. van Beek, J. D. Dodd, R. W. Costello, and H. A. W. M. Tiddens, "Asthma and cystic fibrosis: a tangled web," Pediatric Pulmonology, vol. 49, no. 3, pp. 205-213, 2014.
[156] M. Dahl, A. Tybjærg-Hansen, P. Lange, and B. G. Nordestgaard, " $\Delta$ F508 heterozygosity in cystic fibrosis and susceptibility to asthma," The Lancet, vol. 351, no. 9120, pp. 1911-1913, 1998.

[157] A. Schulz and B. Tümmler, "Non-allergic asthma as a CFTRrelated disorder," Journal of Cystic Fibrosis, 2015.

[158] M. Tzetis, A. Efthymiadou, S. Strofalis et al., "CFTR gene mutations-including three novel nucleotide substitutions- and haplotype background in patients with asthma, disseminated bronchiectasis and chronic obstructive pulmonary disease," Human Genetics, vol. 108, no. 3, pp. 216-221, 2001.

[159] J. P. Garnett, E. Hickman, R. Burrows et al., "Novel role for pendrin in orchestrating bicarbonate secretion in cystic fibrosis transmembrane conductance regulator (CFTR)-expressing airway serous cells," The Journal of Biological Chemistry, vol. 286, no. 47, pp. 41069-41082, 2011.

[160] D. A. Kuperman, C. C. Lewis, P. G. Woodruff et al., "Dissecting asthma using focused transgenic modeling and functional genomics," Journal of Allergy and Clinical Immunology, vol. 116, no. 2, pp. 305-311, 2005.

[161] N. Pedemonte, E. Caci, E. Sondo et al., "Thiocyanate transport in resting and IL-4-stimulated human bronchial epithelial cells: role of pendrin and anion channels," Journal of Immunology, vol. 178, no. 8, pp. 5144-5153, 2007.

[162] I. Nakao, S. Kanaji, S. Ohta et al., "Identification of pendrin as a common mediator for mucus production in bronchial asthma and chronic obstructive pulmonary disease," Journal of Immunology, vol. 180, no. 9, pp. 6262-6269, 2008.

[163] C. A. Bertrand, R. Zhang, J. M. Pilewski, and R. A. Frizzell, "SLC26A9 is a constitutively active, CFTR-regulated anion conductance in human bronchial epithelia," Journal of General Physiology, vol. 133, no. 4, pp. 421-438, 2009.

[164] M.-H. Chang, C. Plata, K. Zandi-Nejad et al., "Slc26a9-anion exchanger, channel and $\mathrm{Na}^{+}$transporter," Journal of Membrane Biology, vol. 228, no. 3, pp. 125-140, 2009.

[165] M. R. Dorwart, N. Shcheynikov, Y. Wang, S. Stippec, and S. Muallem, "SLC26A9 is a Cl- channel regulated by the WNK kinases," Journal of Physiology, vol. 584, no. 1, pp. 333-345, 2007.

[166] A. F. Peery, E. S. Dellon, J. Lund et al., "Burden of gastrointestinal disease in the United States: 2012 update," Gastroenterology, vol. 143, no. 5, pp. 1179-1187.e3, 2012.

[167] P. Hegyi, S. Pandol, V. Venglovecz, and Z. Rakonczay Jr., "The acinar-ductal tango in the pathogenesis of acute pancreatitis," Gut, vol. 60, no. 4, pp. 544-552, 2011.

[168] P. Hegyi, J. Maléth, V. Venglovecz, and Z. Rakonczay Jr., "Pancreatic ductal bicarbonate secretion: challenge of the acinar acid load," Frontiers in Physiology, vol. 2, article 36, 2011.

[169] P. Pallagi, V. Venglovecz, Z. Rakonczay et al., "Trypsin reduces pancreatic ductal bicarbonate secretion by inhibiting CFTR $\mathrm{Cl}^{-}$ channels and luminal anion exchangers," Gastroenterology, vol. 141, no. 6, pp. 2228.e6-2239.e6, 2011.

[170] M. C. Steward and H. Ishiguro, "Molecular and cellular regulation of pancreatic duct cell function," Current Opinion in Gastroenterology, vol. 25, no. 5, pp. 447-453, 2009.

[171] M. C. Steward, H. Ishiguro, and R. M. Case, "Mechanisms of bicarbonate secretion in the pancreatic duct," Annual Review of Physiology, vol. 67, pp. 377-409, 2005.

[172] S. B. H. Ko, W. Zeng, M. R. Dorwart et al., "Gating of CFTR by the STAS domain of SLC26 transporters," Nature Cell Biology, vol. 6, no. 4, pp. 343-350, 2004.

[173] M. A. Gray, "Bicarbonate secretion: it takes two to tango," Nature Cell Biology, vol. 6, no. 4, pp. 292-294, 2004. 
[174] P. Hegyi, Z. Rakonczay, K. Farkas et al., "Controversies in the role of SLC26 anion exchangers in pancreatic ductal bicarbonate secretion," Pancreas, vol. 37, no. 2, pp. 232-234, 2008.

[175] J. Maléth, A. Balázs, P. Pallagi et al., "Alcohol disrupts levels and function of the cystic fibrosis transmembrane conductance regulator to promote development of pancreatitis," Gastroenterology, vol. 148, no. 2, pp. 427-439.e16, 2015.

[176] L. Judák, P. Hegyi, Z. Rakonczay Jr., J. Maléth, M. A. Gray, and V. Venglovecz, "Ethanol and its non-oxidative metabolites profoundly inhibit CFTR function in pancreatic epithelial cells which is prevented by ATP supplementation," Pflugers Archiv European Journal of Physiology, vol. 466, no. 3, pp. 549-562, 2014.

[177] V. Venglovecz, Z. Rakonczay Jr., B. Ózsvári et al., "Effects of bile acids on pancreatic ductal bicarbonate secretion in guinea pig," Gut, vol. 57, no. 8, pp. 1102-1112, 2008.

[178] J. Maléth, V. Venglovecz, Z. Rázga, L. Tiszlavicz, Z. Rakonczay Jr., and P. Hegyi, "Non-conjugated chenodeoxycholate induces severe mitochondrial damage and inhibits bicarbonate transport in pancreatic duct cells," Gut, vol. 60, no. 1, pp. 136-138, 2011.

[179] J. Maléth, P. Hegyi, Z. Rakonczay, and V. Venglovecz, "Breakdown of bioenergetics evoked by mitochondrial damage in acute pancreatitis: mechanisms and consequences," Pancreatology, vol. 15, supplement 4, pp. S18-S22, 2015.

[180] J. Maléth and P. Hegyi, "Calcium signaling in pancreatic ductal epithelial cells: an old friend and a nasty enemy," Cell Calcium, vol. 55, no. 6, pp. 337-345, 2014.

[181] X. Ye, G. Lu, J. Huai, and J. Ding, "Impact of smoking on the risk of pancreatitis: a systematic review and meta-analysis," PLoS ONE, vol. 10, no. 4, Article ID e0124075, 2015.

[182] S. Majumder, J. M. Gierisch, and L. A. Bastian, "The association of smoking and acute pancreatitis: a systematic review and meta-analysis," Pancreas, vol. 44, no. 4, pp. 540-546, 2015.

[183] H. Yuhara, M. Ogawa, Y. Kawaguchi, M. Igarashi, and T. Mine, "Smoking and risk for acute pancreatitis a systematic review and meta-analysis," Pancreas, vol. 43, no. 8, pp. 1201-1207, 2014.

[184] S. V. Raju, P. L. Jackson, C. A. Courville et al., "Cigarette smoke induces systemic defects in cystic fibrosis transmembrane conductance regulator function," American Journal of Respiratory and Critical Care Medicine, vol. 188, no. 11, pp. 1321-1330, 2013.

[185] M. M. Lerch and F. S. Gorelick, "Early trypsinogen activation in acute pancreatitis," Medical Clinics of North America, vol. 84, no. 3, pp. 549-563, 2000.

[186] I. G. Renner, H. Rinderknecht, and A. P. Douglas, "Profiles of pure pancreatic secretions in patients with acute pancreatitis: the possible role of proteolytic enzymes in pathogenesis," Gastroenterology, vol. 75, no. 6, pp. 1090-1098, 1978.

[187] M. C. Geokas and H. Rinderknecht, "Free proteolytic enzymes in pancreatic juice of patients with acute pancreatitis," The American Journal of Digestive Diseases, vol. 19, no. 7, pp. 591598, 1974.

[188] N. Sharer, M. Schwarz, G. Malone et al., "Mutations of the cystic fibrosis gene in patients with chronic pancreatitis," The New England Journal of Medicine, vol. 339, no. 10, pp. 645-652, 1998.

[189] C. Castellani, A. Bonizzato, R. Rolfini, L. Frulloni, G. C. Cavallini, and G. Mastella, "Increased prevalence of mutations of the cystic fibrosis gene in idiopathic chronic and recurrent pancreatitis," The American Journal of Gastroenterology, vol. 94, no. 7, pp. 1993-1995, 1999.
[190] J. A. Cohn, K. J. Friedman, P. G. Noone, M. R. Knowles, L. M. Silverman, and P. S. Jowell, "Relation between mutations of the cystic fibrosis gene and idiopathic pancreatitis," The New England Journal of Medicine, vol. 339, no. 10, pp. 653-658, 1998.

[191] J. A. Cohn, J. P. Neoptolemos, J. Feng et al., "Increased risk of idiopathic chronic pancreatitis in cystic fibrosis carriers," Human Mutation, vol. 26, no. 4, pp. 303-307, 2005.

[192] P. G. Noone, Z. Zhou, L. M. Silverman, P. S. Jowell, M. R. Knowles, and J. A. Cohn, "Cystic fibrosis gene mutations and pancreatitis risk: relation to epithelial ion transport and trypsin inhibitor gene mutations," Gastroenterology, vol. 121, no. 6, pp. 1310-1319, 2001.

[193] J. Ockenga, M. Stuhrmann, M. Ballmann et al., "Mutations of the cystic fibrosis gene, but not cationic trypsinogen gene, are associated with recurrent or chronic idiopathic pancreatitis," American Journal of Gastroenterology, vol. 95, no. 8, pp. 20612067, 2000.

[194] K. Truninger, N. Malik, R. W. Ammann et al., "Mutations of the cystic fibrosis gene in patients with chronic pancreatitis," The American Journal of Gastroenterology, vol. 96, no. 9, pp. 26572661, 2001.

[195] J. LaRusch, J. Jung, I. J. General et al., "Mechanisms of CFTR functional variants that impair regulated bicarbonate permeation and increase risk for pancreatitis but not for cystic fibrosis," PLoS Genetics, vol. 10, no. 7, Article ID e1004376, 2014.

[196] E. Masson, J.-M. Chen, M.-P. Audrézet, D. N. Cooper, and C. Férec, "A conservative assessment of the major genetic causes of idiopathic chronic pancreatitis: data from a comprehensive analysis of PRSS1, SPINK1, CTRC and CFTR Genes in 253 young french patients," PLOS ONE, vol. 8, no. 8, Article ID e73522, 2013.

[197] J. Rosendahl, O. Landt, J. Bernadova et al., "CFTR, SPINK1, CTRC and PRSS1 variants in chronic pancreatitis: Is the role of mutated CFTR overestimated?” Gut, vol. 62, no. 4, pp. 582-592, 2013.

[198] C. Y. Ooi and P. R. Durie, "Cystic fibrosis transmembrane conductance regulator (CFTR) gene mutations in pancreatitis," Journal of Cystic Fibrosis, vol. 11, no. 5, pp. 355-362, 2012.

[199] V. Ravi Kanth and D. Nageshwar Reddy, "Genetics of acute and chronic pancreatitis: an update," World Journal of Gastrointestinal Pathophysiology, vol. 5, no. 4, pp. 427-437, 2014.

[200] P. Hegyi and Z. Rakonczay, "Insufficiency of electrolyte and fluid secretion by pancreatic ductal cells leads to increased patient risk for pancreatitis," American Journal of Gastroenterology, vol. 105, no. 9, pp. 2119-2120, 2010.

[201] C. Y. Ooi, R. Dorfman, M. Cipolli et al., "Type of CFTR mutation determines risk of pancreatitis in patients with cystic fibrosis," Gastroenterology, vol. 140, no. 1, pp. 153-161, 2011.

[202] R. Makhija and A. N. Kingsnorth, "Cytokine storm in acute pancreatitis," Journal of Hepato-Biliary-Pancreatic Surgery, vol. 9, no. 4, pp. 401-410, 2002.

[203] R. Pezzilli, P. Billi, R. Miniero et al., "Serum interleukin-6, interleukin-8, and $\beta 2$-microglobulin in early assessment of severity of acute pancreatitis comparison with serum C-reactive protein," Digestive Diseases and Sciences, vol. 40, no. 11, pp. 23412348, 1995.

[204] V. Gross, R. Andreesen, H.-G. Leser et al., "Interleukin-8 and neutrophil activation in acute pancreatitis," European Journal of Clinical Investigation, vol. 22, no. 3, pp. 200-203, 1992.

[205] D. Kempuraj, E. C. Twait, D. E. Williard, Z. Yuan, D. K. Meyerholz, and I. Samuel, "The novel cytokine interleukin33 activates acinar cell proinflammatory pathways and induces 
acute pancreatic inflammation in mice," PLoS ONE, vol. 8, no. 2, article e56866, 2013.

[206] Y. Motoo, M. J. Xie, H. Mouri, and N. Sawabu, "Expression of interleukin-8 in human obstructive pancreatitis," Journal of the Pancreas, vol. 5, no. 3, pp. 138-144, 2004.

[207] T. A. Blinman, I. Gukovsky, M. Mouria et al., "Activation of pancreatic acinar cells on isolation from tissue: cytokine upregulation via p38 MAP kinase," American Journal of PhysiologyCell Physiology, vol. 279, no. 6, pp. C1993-C2003, 2000.

[208] M.-J. Xie, Y. Motoo, S.-B. Su, H. Mouri, and N. Sawabu, "Induction of chemokines in rat pancreatic acinar cell injury," Pancreas, vol. 24, no. 2, pp. 198-204, 2002.

[209] B. Movahedi, C. Gysemans, D. Jacobs-Tulleneers-Thevissen, C. Mathieu, and D. Pipeleers, "Pancreatic duct cells in human islet cell preparations are a source of angiogenic cytokines interleukin-8 and vascular endothelial growth factor," Diabetes, vol. 57, no. 8, pp. 2128-2136, 2008.

[210] J. A. Blanchard II, S. Barve, S. Joshi-Barve, R. Talwalker, and L. K. Gates Jr., "Cytokine production by CAPAN-1 and CAPAN2 cell lines," Digestive Diseases and Sciences, vol. 45, no. 5, pp. 927-932, 2000.

[211] M. Rowland, C. Gallagher, C. G. Gallagher et al., "Outcome in patients with cystic fibrosis liver disease," Journal of Cystic Fibrosis, vol. 14, no. 1, pp. 120-126, 2015.

[212] J. A. Cohn, T. V. Strong, M. R. Picciotto, A. C. Nairn, F. S. Collins, and J. G. Fitz, "Localization of the cystic fibrosis transmembrane conductance regulator in human bile duct epithelial cells," Gastroenterology, vol. 105, no. 6, pp. 1857-1864, 1993.

[213] J. M. Banales, F. Arenas, C. M. Rodríguez-Ortigosa et al., "Bicarbonate-rich choleresis induced by secretin in normal rat is taurocholate-dependent and involves AE2 anion exchanger," Hepatology, vol. 43, no. 2, pp. 266-275, 2006.

[214] J. M. Banales, J. Prieto, and J. F. Medina, "Cholangiocyte anion exchange and biliary bicarbonate excretion," World Journal of Gastroenterology, vol. 12, no. 22, pp. 3496-3511, 2006.

[215] N. Minagawa, J. Nagata, K. Shibao et al., "Cyclic AMP regulates bicarbonate secretion in cholangiocytes through release of ATP into bile," Gastroenterology, vol. 133, no. 5, pp. 1592-1602, 2007.

[216] A. Uc, R. Giriyappa, D. K. Meyerholz et al., "Pancreatic and biliary secretion are both altered in cystic fibrosis pigs," American Journal of Physiology-Gastrointestinal and Liver Physiology, vol. 303, no. 8, pp. G961-G968, 2012.

[217] R. A. Nagel, A. Javaid, H. B. Meire et al., "Liver disease and bile duct abnormalities in adults with cystic fibrosis," The Lancet, vol. 334, no. 8677, pp. 1422-1425, 1989.

[218] U. Herrmann, G. Dockter, and F. Lammert, "Cystic fibrosisassociated liver disease," Best Practice and Research: Clinical Gastroenterology, vol. 24, no. 5, pp. 585-592, 2010.

[219] T. Kelly and J. Buxbaum, "Gastrointestinal manifestations of cystic fibrosis," Digestive Diseases and Sciences, vol. 60, no. 7, pp. 1903-1913, 2015.

[220] K. Harada and Y. Nakanuma, "Biliary innate immunity: function and modulation," Mediators of Inflammation, vol. 2010, Article ID 373878, 9 pages, 2010.

[221] K. Harada and Y. Nakanuma, "Innate immunity in the pathogenesis of cholangiopathy: a recent update," Inflammation and Allergy-Drug Targets, vol. 11, no. 6, pp. 478-483, 2012.

[222] R. Dong and S. Zheng, "Interleukin-8: a critical chemokine in biliary atresia," Journal of Gastroenterology and Hepatology, vol. 30, no. 6, pp. 970-976, 2015.
[223] J. Choi, C. Selmi, P. S. Leung, T. P. Kenny, T. Roskams, and M. E. Gershwin, "Chemokine and chemokine receptors in autoimmunity: the case of primary biliary cholangitis," Expert Review of Clinical Immunology, vol. 12, no. 6, pp. 661-672, 2016.

[224] C. M. Morland, J. Fear, G. McNab, R. Joplin, and D. H. Adams, "Promotion of leukocyte transendothelial cell migration by chemokines derived from human biliary epithelial cells in vitro," Proceedings of the Association of American Physicians, vol. 109, no. 4, pp. 372-382, 1997.

[225] E. A. Kruglov, R. A. Nathanson, T. Nguyen, and J. A. Dranoff, "Secretion of MCP-1/CCL2 by bile duct epithelia induces myofibroblastic transdifferentiation of portal fibroblasts," American Journal of Physiology-Gastrointestinal and Liver Physiology, vol. 290, no. 4, pp. G765-G771, 2006.

[226] K. Isse, K. Harada, and Y. Nakanuma, "IL-8 expression by biliary epithelial cells is associated with neutrophilic infiltration and reactive bile ductules," Liver International, vol. 27, no. 5, pp. 672680, 2007.

[227] S. Shimoda, K. Harada, H. Niiro et al., "Biliary epithelial cells and primary biliary cirrhosis: the role of liver-infiltrating mononuclear cells," Hepatology, vol. 47, no. 3, pp. 958-965, 2008.

[228] C. Spiral, M. H. Nathanson, R. Fiorotto et al., "Proinflammatory cytokines inhibit secretion in rat bile duct epithelium," Gastroenterology, vol. 121, no. 1, pp. 156-169, 2001.

[229] R. Fiorotto, R. Scirpo, M. Trauner et al., "Loss of CFTR affects biliary epithelium innate immunity and causes TLR4NF- $\kappa$ Bmediated inflammatory response in mice," Gastroenterology, vol. 141, no. 4, pp. 1498-1508, 2011.

[230] P. G. Blanco, M. M. Zaman, O. Junaidi et al., "Induction of colitis in $\mathrm{ctrr}^{-1-}$ mice results in bile duct injury," American Journal of Physiology-Gastrointestinal and Liver Physiology, vol. 287, no. 2, pp. G491-G496, 2004.

[231] J. F. Medina, E. Martínez-Ansó, J. J. Vázquez, and J. Prieto, "Decreased anion exchanger 2 immunoreactivity in the liver of patients with primary biliary cirrhosis," Hepatology, vol. 25, no. 1, pp. 12-17, 1997.

[232] C. Demeilliers, E. Jacquemin, V. Barbu et al., "Altered hepatobiliary gene expressions in PFIC1: ATP8B1 gene defect is associated with CFTR downregulation," Hepatology, vol. 43, no. 5, pp. 11251134, 2006.

[233] H. Pall, J. Zielenski, M. M. Jonas et al., "Primary sclerosing cholangitis in childhood is associated with abnormalities in cystic fibrosis-mediated chloride channel function," Journal of Pediatrics, vol. 151, no. 3, pp. 255-259, 2007.

[234] L. Henckaerts, M. Jaspers, W. Van Steenbergen et al., "Cystic fibrosis transmembrane conductance regulator gene polymorphisms in patients with primary sclerosing cholangitis," Journal of Hepatology, vol. 50, no. 1, pp. 150-157, 2009.

[235] R. Tarran, L. Trout, S. H. Donaldson, and R. C. Boucher, "Soluble mediators, not cilia, determine airway surface liquid volume in normal and cystic fibrosis superficial airway epithelia," Journal of General Physiology, vol. 127, no. 5, pp. 591-604, 2006.

[236] R. Tarran, B. R. Grubb, J. T. Gatzy, C. W. Davis, and R. C. Boucher, "The relative roles of passive surface forces and active ion transport in the modulation of airway surface liquid volume and composition," Journal of General Physiology, vol. 118, no. 2, pp. 223-236, 2001.

[237] U. Griesenbach, S. Soussi, M. B. Larsen et al., "Quantification of periciliary fluid height in human airway biopsies is feasible, but not suitable as a biomarker," American Journal of Respiratory Cell and Molecular Biology, vol. 44, no. 3, pp. 309-315, 2011. 
[238] C. A. Hobbs, C. Da Tan, and R. Tarran, "Does epithelial sodium channel hyperactivity contribute to cystic fibrosis lung disease?" Journal of Physiology, vol. 591, no. 18, pp. 4377-4387, 2013.

[239] O. A. Itani, J.-H. Chen, P. H. Karp et al., "Human cystic fibrosis airway epithelia have reduced $\mathrm{Cl}^{-}$conductance but not increased $\mathrm{Na}^{+}$conductance," Proceedings of the National Academy of Sciences of the United States of America, vol. 108, no. 25, pp. 10260-10265, 2011.

[240] J.-H. Chen, D. A. Stoltz, P. H. Karp et al., "Loss of anion transport without increased sodium absorption characterizes newborn porcine cystic fibrosis airway epithelia," Cell, vol. 143, no. 6, pp. 911-923, 2010.

[241] M. R. Elkins, M. Robinson, B. R. Rose et al., "A controlled trial of long-term inhaled hypertonic saline in patients with cystic fibrosis," The New England Journal of Medicine, vol. 354, no. 3, pp. 229-240, 2006.

[242] S. H. Donaldson, W. D. Bennett, K. L. Zeman, M. R. Knowles, R. Tarran, and R. C. Boucher, "Mucus clearance and lung function in cystic fibrosis with hypertonic saline," The New England Journal of Medicine, vol. 354, no. 3, pp. 241-250, 2006.

[243] M. M. Chan, K. Chmura, and E. D. Chan, "Increased NaClinduced interleukin- 8 production by human bronchial epithelial cells is enhanced by the $\Delta \mathrm{F} 508 / \mathrm{W} 1282 \mathrm{X}$ mutation of the cystic fibrosis transmembrane conductance regulator gene," Cytokine, vol. 33, no. 6, pp. 309-316, 2006.

[244] S. Hashimoto, K. Matsumoto, Y. Gon, T. Nakayama, I. Takeshita, and T. Horie, "Hyperosmolarity-induced interleukin-8 expression in human bronchial epithelial ceils through p38 mitogenactivated protein kinase," American Journal of Respiratory and Critical Care Medicine, vol. 159, no. 2, pp. 634-640, 1999.

[245] R. Suri, L. J. Marshall, C. Wallis, C. Metcalfe, A. Bush, and J. K. Shute, "Effects of recombinant human DNase and hypertonic saline on airway inflammation in children with cystic fibrosis," American Journal of Respiratory and Critical Care Medicine, vol. 166, no. 3, pp. 352-355, 2002.

[246] M. L. Aitken, K. E. Greene, M. R. Tonelli et al., "Analysis of sequential aliquots of hypertonic saline solution-induced sputum from clinically stable patients with cystic fibrosis," Chest, vol. 123, no. 3, pp. 792-799, 2003.

[247] E. P. Reeves, M. Williamson, S. J. O’Neill, P. Greally, and N. G. McElvaney, "Nebulized hypertonic saline decreases IL-8 in sputum of patients with cystic fibrosis," American Journal of Respiratory and Critical Care Medicine, vol. 183, no. 11, pp. 15171523, 2011.

[248] B. Goger, Y. Halden, A. Rek et al., "Different affinities of glycosaminoglycan oligosaccharides for monomeric and dimeric interleukin-8: a model for chemokine regulation at inflammatory sites," Biochemistry, vol. 41, no. 5, pp. 1640-1646, 2002.

[249] L. J. Marshall, L. S. P. Ramdin, T. Brooks, P. C. DPhil, and J. K. Shute, "Plasminogen activator inhibitor-1 supports IL8-mediated neutrophil transendothelial migration by inhibition of the constitutive shedding of endothelial IL-8/heparan sulfate/syndecan-1 complexes," Journal of Immunology, vol. 171, no. 4, pp. 2057-2065, 2003.

[250] M. M. Farberman, A. Ibricevic, T. D. Joseph et al., "Effect of polarized release of CXC-chemokines from wild-type and cystic fibrosis murine airway epithelial cells," American Journal of Respiratory Cell and Molecular Biology, vol. 45, no. 2, pp. 221228, 2011.

[251] S. D. Freedman, H. F. Kern, and G. A. Scheele, "Pancreatic acinar cell dysfunction in $\mathrm{CFTR}^{-/-}$mice is associated with impairments in luminal pH and endocytosis," Gastroenterology, vol. 121, no. 4, pp. 950-957, 2001.

[252] A. L. Garland, W. G. Walton, R. D. Coakley et al., "Molecular basis for $\mathrm{pH}$-dependent mucosal dehydration in cystic fibrosis airways," Proceedings of the National Academy of Sciences of the United States of America, vol. 110, no. 40, pp. 15973-15978, 2013.

[253] R. D. Coakley, B. R. Grubb, A. M. Paradiso et al., "Abnormal surface liquid $\mathrm{pH}$ regulation by cultured cystic fibrosis bronchial epithelium," Proceedings of the National Academy of Sciences of the United States of America, vol. 100, no. 26, pp. 16083-16088, 2003.

[254] Y. Song, D. Salinas, D. W. Nielson, and A. S. Verkman, "Hyperacidity of secreted fluid from submucosal glands in early cystic fibrosis," American Journal of Physiology-Cell Physiology, vol. 290, no. 3, pp. C741-C749, 2006.

[255] J. H. Poulsen, H. Fischer, B. Illek, and T. E. Machen, "Bicarbonate conductance and $\mathrm{pH}$ regulatory capability of cystic fibrosis transmembrane conductance regulator," Proceedings of the National Academy of Sciences of the United States of America, vol. 91, no. 12, pp. 5340-5344, 1994.

[256] J. J. Smith and M. J. Welsh, "cAMP stimulates bicarbonate secretion across normal, but not cystic fibrosis airway epithelia," Journal of Clinical Investigation, vol. 89, no. 4, pp. 1148-1153, 1992.

[257] S. B. H. Ko, N. Shcheynikov, J. Y. Choi et al., "A molecular mechanism for aberrant CFTR-dependent $\mathrm{CO}_{3}{ }^{-}$transport in cystic fibrosis," The EMBO Journal, vol. 21, no. 21, pp. 5662-5672, 2002.

[258] V. S. Shah, D. K. Meyerholz, X. X. Tang et al., "Airway acidification initiates host defense abnormalities in cystic fibrosis mice," Science, vol. 351, no. 6272, pp. 503-507, 2016.

[259] A. Schütte, A. Ermund, C. Becker-Pauly et al., "Microbialinduced meprin $\beta$ cleavage in MUC2 mucin and a functional CFTR channel are required to release anchored small intestinal mucus," Proceedings of the National Academy of Sciences of the United States of America, vol. 111, no. 34, pp. 12396-12401, 2014.

[260] N. Yang, M. A. S. Garcia, and P. M. Quinton, "Normal mucus formation requires cAMP-dependent $\mathrm{HCO}_{3}$ - secretion and $\mathrm{Ca}^{2+}$-mediated mucin exocytosis," Journal of Physiology, vol. 591, no. 18, pp. 4581-4593, 2013.

[261] J. K. Gustafsson, A. Ermund, D. Ambort et al., "Bicarbonate and functional CFTR channel are required for proper mucin secretion and link cystic fibrosis with its mucus phenotype," The Journal of Experimental Medicine, vol. 209, no. 7, pp. 1263-1272, 2012.

[262] M. J. Hoegger, A. J. Fischer, J. D. McMenimen et al., "Impaired mucus detachment disrupts mucociliary transport in a piglet model of cystic fibrosis," Science, vol. 345, no. 6198, pp. 818-822, 2014.

[263] M. A. S. Garcia, N. Yang, and P. M. Quinton, "Normal mouse intestinal mucus release requires cystic fibrosis transmembrane regulator-dependent bicarbonate secretion," Journal of Clinical Investigation, vol. 119, no. 9, pp. 2613-2622, 2009.

[264] K. R. Bhaskar, D. Gong, R. Bansil et al., "Profound increase in viscosity and aggregation of pig gastric mucin at low $\mathrm{pH}$," American Journal of Physiology-Gastrointestinal and Liver Physiology, vol. 261, no. 5, part 1, pp. G827-G832, 1991.

[265] M. H. Abou Alaiwa, L. R. Reznikov, N. D. Gansemer et al., " $\mathrm{pH}$ modulates the activity and synergism of the airway surface liquid antimicrobials $\beta$-defensin- 3 and LL-37," Proceedings of the National Academy of Sciences of the United States of America, vol. 111, no. 52, pp. 18703-18708, 2014. 
[266] C. R. Justus, L. Dong, and L. V. Yang, "Acidic tumor microenvironment and $\mathrm{pH}$-sensing $\mathrm{G}$ protein-coupled receptors," Frontiers in Physiology, vol. 4, article 354, 2013.

[267] A. Chen, L. Dong, N. R. Leffler, A. S. Asch, O. N. Witte, and L. V. Yang, "Activation of GPR4 by acidosis increases endothelial cell adhesion through the cAMP/Epac pathway," PLoS ONE, vol. 6, no. 11, Article ID e27586, 2011.

[268] M.-G. Ludwig, M. Vanek, D. Guerini et al., "Proton-sensing Gprotein-coupled receptors," Nature, vol. 425, no. 6953, pp. 9398, 2003.

[269] L. Dong, Z. Li, N. R. Leffler, A. S. Asch, J.-T. Chi, and L. V. Yang, "Acidosis activation of the proton-sensing GPR4 receptor stimulates vascular endothelial cell inflammatory responses revealed by transcriptome analysis," PLoS ONE, vol. 8, no. 4, Article ID e61991, 2013.

[270] C. Liu, Q. Li, X. Zhou, V. P. Kolosov, and J. M. Perelman, "Regulator of G-protein signaling 2 inhibits acid-induced mucin5AC hypersecretion in human airway epithelial cells," Respiratory Physiology and Neurobiology, vol. 185, no. 2, pp. 265-271, 2013.

[271] I. Ichimonji, H. Tomura, C. Mogi et al., "Extracellular acidification stimulates IL-6 production and $\mathrm{Ca}^{2+}$ mobilization through proton-sensing OGR1 receptors in human airway smooth muscle cells," American Journal of Physiology-Lung Cellular and Molecular Physiology, vol. 299, no. 4, pp. L567L577, 2010.

[272] L. A. Skelton and W. F. Boron, "Effect of acute acid-base disturbances on ErbB1/2 tyrosine phosphorylation in rabbit renal proximal tubules," American Journal of Physiology-Renal Physiology, vol. 305, no. 12, pp. F1747-F1764, 2013.

[273] S. Kim, B. A. Beyer, C. Lewis, and J. A. Nadel, "Normal CFTR inhibits epidermal growth factor receptor-dependent pro-inflammatory chemokine production in human airway epithelial cells," PLoS ONE, vol. 8, no. 8, Article ID e72981, 2013.

[274] A. Garcia-Caballero, J. E. Rasmussen, E. Gaillard et al., "SPLUNC1 regulates airway surface liquid volume by protecting ENaC from proteolytic cleavage," Proceedings of the National Academy of Sciences of the United States of America, vol. 106, no. 27, pp. 11412-11417, 2009.

[275] P. Linsdell and J. W. Hanrahan, "Glutathione permeability of CFTR," American Journal of Physiology-Cell Physiology, vol. 275, no. 1, pp. C323-C326, 1998.

[276] L. Gao, K. J. Kim, J. R. Yankaskas, and H. J. Forman, "Abnormal glutathione transport in cystic fibrosis airway epithelia," American Journal of Physiology-Lung Cellular and Molecular Physiology, vol. 277, no. 1, pp. L113-L118, 1999.

[277] P. Linsdell, "Thiocyanate as a probe of the cystic fibrosis transmembrane conductance regulator chloride channel pore," Canadian Journal of Physiology and Pharmacology, vol. 79, no. 7, pp. 573-579, 2001.

[278] M. A. Fragoso, V. Fernandez, R. Forteza, S. H. Randell, M. Salathe, and G. E. Conner, "Transcellular thiocyanate transport by human airway epithelia," Journal of Physiology, vol. 561, no. 1, pp. 183-194, 2004.

[279] A. M. Cantin, S. L. North, R. C. Hubbard, and R. G. Crystal, "Normal alveolar epithelial lining fluid contains high levels of glutathione," Journal of Applied Physiology, vol. 63, no. 1, pp. 152157, 1987.

[280] J. H. Roum, R. Buhl, N. G. McElvaney, Z. Borok, and R. G. Crystal, "Systemic deficiency of glutathione in cystic fibrosis," Journal of Applied Physiology, vol. 75, no. 6, pp. 2419-2424, 1993.

[281] F. Galli, A. Battistoni, R. Gambari et al., "Oxidative stress and antioxidant therapy in cystic fibrosis," Biochimica et Biophysica
Acta (BBA)-Molecular Basis of Disease, vol. 1822, no. 5, pp. 690-713, 2012.

[282] A. G. Ziady and J. Hansen, "Redox balance in cystic fibrosis," International Journal of Biochemistry and Cell Biology, vol. 52, pp. 113-123, 2014.

[283] H. Fischer, "Mechanisms and function of DUOX in epithelia of the lung," Antioxidants \& Redox Signaling, vol. 11, no. 10, pp. 2453-2465, 2009.

[284] M. Geiszt, J. Witta, J. Baffi, K. Lekstrom, and T. L. Leto, "Dual oxidases represent novel hydrogen peroxide sources supporting mucosal surface host defense," The FASEB Journal, vol. 17, no. 11, pp. 1502-1504, 2003.

[285] P.-R. Burgel and J. A. Nadel, "Epidermal growth factor receptormediated innate immune responses and their roles in airway diseases," European Respiratory Journal, vol. 32, no. 4, pp. 10681081, 2008.

[286] J. Bérubé, L. Roussel, L. Nattagh, and S. Rousseau, "Loss of cystic fibrosis transmembrane conductance regulator function enhances activation of p38 and erk mapks, increasing interleukin-6 synthesis in airway epithelial cells exposed to Pseudomonas aeruginosa," Journal of Biological Chemistry, vol. 285, no. 29, pp. 22299-22307, 2010.

[287] J. H. Roum, Z. Borok, N. G. McElvaney et al., "Glutathione aerosol suppresses lung epithelial surface inflammatory cellderived oxidants in cystic fibrosis," Journal of Applied Physiology, vol. 87, no. 1, pp. 438-443, 1999.

[288] M. Griese, J. Ramakers, A. Krasselt et al., "Improvement of alveolar glutathione and lung function but not oxidative state in cystic fibrosis," American Journal of Respiratory and Critical Care Medicine, vol. 169, no. 7, pp. 822-828, 2004.

[289] M. Griese, M. Kappler, C. Eismann et al., "Inhalation treatment with glutathione in patients with cystic fibrosis. A randomized clinical trial," American Journal of Respiratory and Critical Care Medicine, vol. 188, no. 1, pp. 83-89, 2013.

[290] G. F. Rushworth and I. L. Megson, "Existing and potential therapeutic uses for $\mathrm{N}$-acetylcysteine: the need for conversion to intracellular glutathione for antioxidant benefits," Pharmacology and Therapeutics, vol. 141, no. 2, pp. 150-159, 2014.

[291] Y. C. M. Duijvestijn and P. L. P. Brand, "Systematic review of Nacetylcysteine in cystic fibrosis," Acta Paediatrica, vol. 88, no. 1, pp. 38-41, 1999.

[292] M. Skov, T. Pressler, J. Lykkesfeldt et al., "The effect of shortterm, high-dose oral $\mathrm{N}$-acetylcysteine treatment on oxidative stress markers in cystic fibrosis patients with chronic P. aeruginosa infection-a pilot study," Journal of Cystic Fibrosis, vol. 14, no. 2, pp. 211-218, 2015.

[293] R. Tirouvanziam, C. K. Conrad, T. Bottiglieri, L. A. Herzenberg, R. B. Moss, and L. A. Herzenberg, "High-dose oral Nacetylcysteine, a glutathione prodrug, modulates inflammation in cystic fibrosis," Proceedings of the National Academy of Sciences of the United States of America, vol. 103, no. 12, pp. 46284633, 2006.

[294] C. Conrad, J. Lymp, V. Thompson et al., "Long-term treatment with oral $\mathrm{N}$-acetylcysteine: affects lung function but not sputum inflammation in cystic fibrosis subjects. A phase II randomized placebo-controlled trial," Journal of Cystic Fibrosis, vol. 14, no. 2, pp. 219-227, 2015.

[295] Y. Xu, S. Szép, and Z. Lu, “The antioxidant role of thiocyanate in the pathogenesis of cystic fibrosis and other inflammationrelated diseases," Proceedings of the National Academy of Sciences of the United States of America, vol. 106, no. 48, pp. 2051520519, 2009. 
[296] P. Moskwa, D. Lorentzen, K. J. D. A. Excoffon et al., "A novel host defense system of airways is defective in cystic fibrosis," American Journal of Respiratory and Critical Care Medicine, vol. 175, no. 2, pp. 174-183, 2007.

[297] N. S. Gould, S. Gauthier, C. T. Kariya, E. Min, J. Huang, and B. J. Day, "Hypertonic saline increases lung epithelial lining fluid glutathione and thiocyanate: two protective CFTR-dependent thiols against oxidative injury," Respiratory Research, vol. 11, article 119, 2010.

[298] Ł. Minarowski, D. Sands, A. Minarowska et al., "Thiocyanate concentration in saliva of cystic fibrosis patients," Folia Histochemica et Cytobiologica, vol. 46, no. 2, pp. 245-246, 2008.

[299] J. D. Chandler, E. Min, J. Huang et al., "Antiinflammatory and antimicrobial effects of thiocyanate in a cystic fibrosis mouse model," American Journal of Respiratory Cell and Molecular Biology, vol. 53, no. 2, pp. 193-205, 2015.

[300] P. A. Sloane, S. Shastry, A. Wilhelm et al., "A pharmacologic approach to acquired cystic fibrosis transmembrane conductance regulator dysfunction in smoking related lung disease," PLoS ONE, vol. 7, no. 6, article e39809, 2012.

[301] ClinicalTrials.gov, "TOPIC trial for COPD," ClinicalTrials.gov NCT02135432, 2014.

[302] F. Van Goor, S. Hadida, P. D. J. Grootenhuis et al., "Rescue of CF airway epithelial cell function in vitro by a CFTR potentiator, VX-770," Proceedings of the National Academy of Sciences of the United States of America, vol. 106, no. 44, pp. 18825-18830, 2009.

[303] M. A. Mall and L. J. V. Galietta, "Targeting ion channels in cystic fibrosis," Journal of Cystic Fibrosis, vol. 14, no. 5, article 1230, pp. 561-570, 2015.

[304] B. R. Yerxa, J. R. Sabater, C. W. Davis et al., "Pharmacology of INS37217 [ $\mathrm{P}^{1}$ (uridine $\left.5^{\prime}\right)-\mathrm{P}^{4}-\left(2^{\prime}\right.$-deoxycytidine $5^{\prime}$ )tetraphosphate, tetrasodium salt], a next-generation $\mathrm{P}_{2} \mathrm{Y}_{2}$ receptor agonist for the treatment of cystic fibrosis," Journal of Pharmacology and Experimental Therapeutics, vol. 302, no. 3, pp. 871-880, 2002.

[305] F. J. Accurso, R. B. Moss, R. W. Wilmott et al., "Denufosol tetrasodium in patients with cystic fibrosis and normal to mildly impaired lung function," American Journal of Respiratory and Critical Care Medicine, vol. 183, no. 5, pp. 627-634, 2011.

[306] R. V. Flores, M. G. Hernández-Pérez, E. Aquino, R. C. Garrad, G. A. Weisman, and F. A. Gonzalez, "Agonist-induced phosphorylation and desensitization of the P2Y2 nucleotide receptor," Molecular and Cellular Biochemistry, vol. 280, no. 1-2, pp. 3545, 2005.

[307] C. Hoffmann, N. Ziegler, S. Reiner, C. Krasel, and M. J. Lohse, "Agonist-selective, receptor-specific interaction of human P2Y receptors with $\beta$-arrestin-1 and -2," Journal of Biological Chemistry, vol. 283, no. 45, pp. 30933-30941, 2008.

[308] G. E. Morris, C. P. Nelson, D. Everitt et al., "G protein-coupled receptor kinase 2 and arrestin 2 regulate arterial smooth muscle P2Y-purinoceptor signalling," Cardiovascular Research, vol. 89, no. 1, pp. 193-203, 2011.

[309] W. Namkung, Z. Yao, W. E. Finkbeiner, and A. S. Verkman, "Small-molecule activators of TMEM16A, a calcium-activated chloride channel, stimulate epithelial chloride secretion and intestinal contraction," The FASEB Journal, vol. 25, no. 11, pp. 4048-4062, 2011.

[310] F. Huang, H. Zhang, M. Wu et al., "Calcium-activated chloride channel TMEM16A modulates mucin secretion and airway smooth muscle contraction," Proceedings of the National Academy of Sciences of the United States of America, vol. 109, no. 40, pp. 16354-16359, 2012.
[311] L. Ferrera, A. Caputo, I. Ubby et al., "Regulation of TMEM16A chloride channel properties by alternative splicing," The Journal of Biological Chemistry, vol. 284, no. 48, pp. 33360-33368, 2009.

[312] C. Calabrese, A. Tosco, P. Abete et al., "Randomized, single blind, controlled trial of inhaled glutathione vs placebo in patients with cystic fibrosis," Journal of Cystic Fibrosis, vol. 14, no. 2, pp. 203-210, 2015.

[313] F. Ratjen, T. Durham, T. Navratil et al., "Long term effects of denufosol tetrasodium in patients with cystic fibrosis," Journal of Cystic Fibrosis, vol. 11, no. 6, pp. 539-549, 2012. 


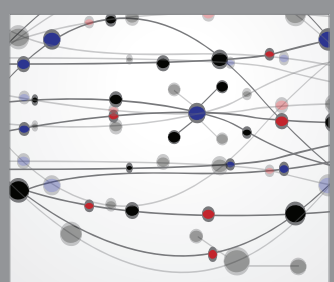

The Scientific World Journal
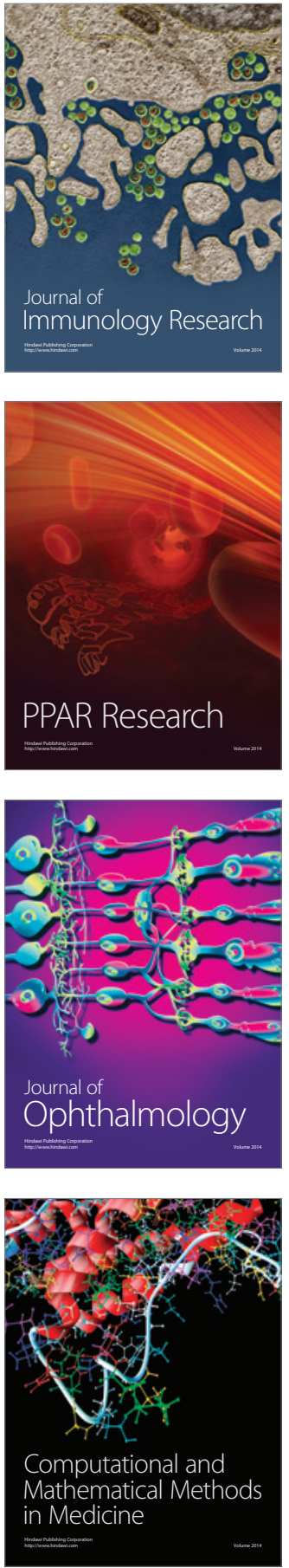

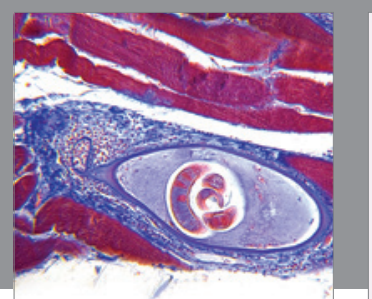

Gastroenterology Research and Practice

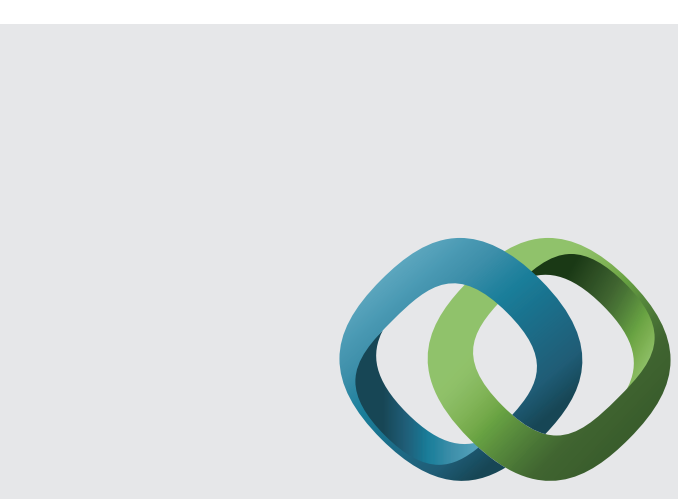

\section{Hindawi}

Submit your manuscripts at

http://www.hindawi.com
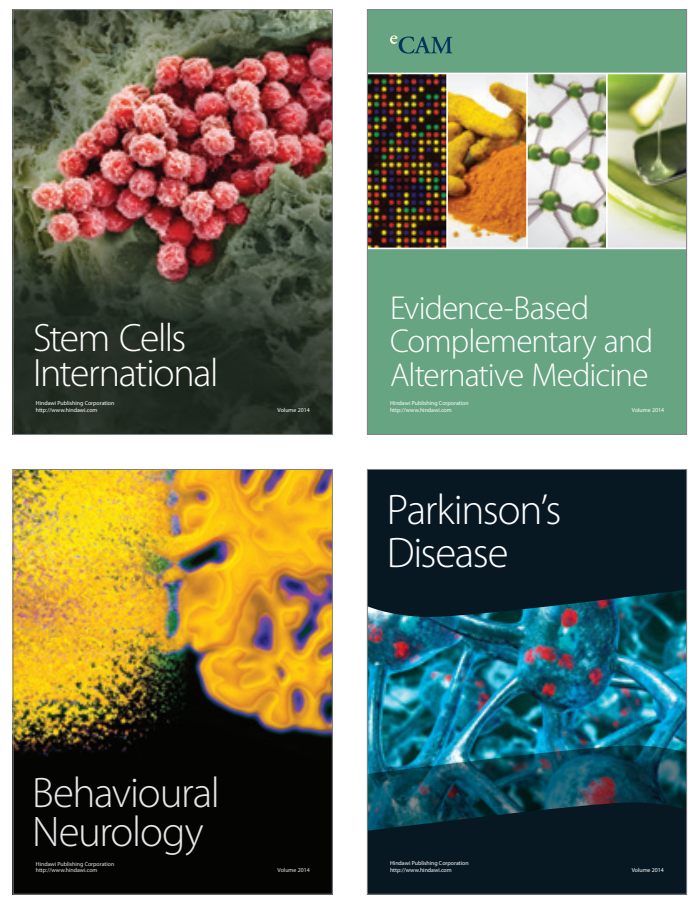
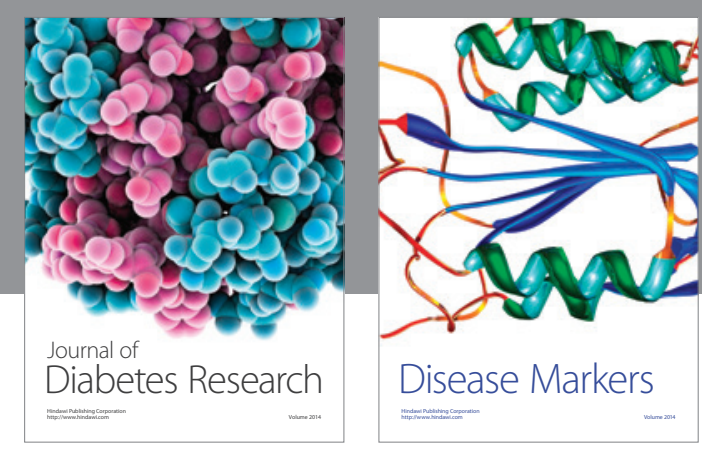

Disease Markers
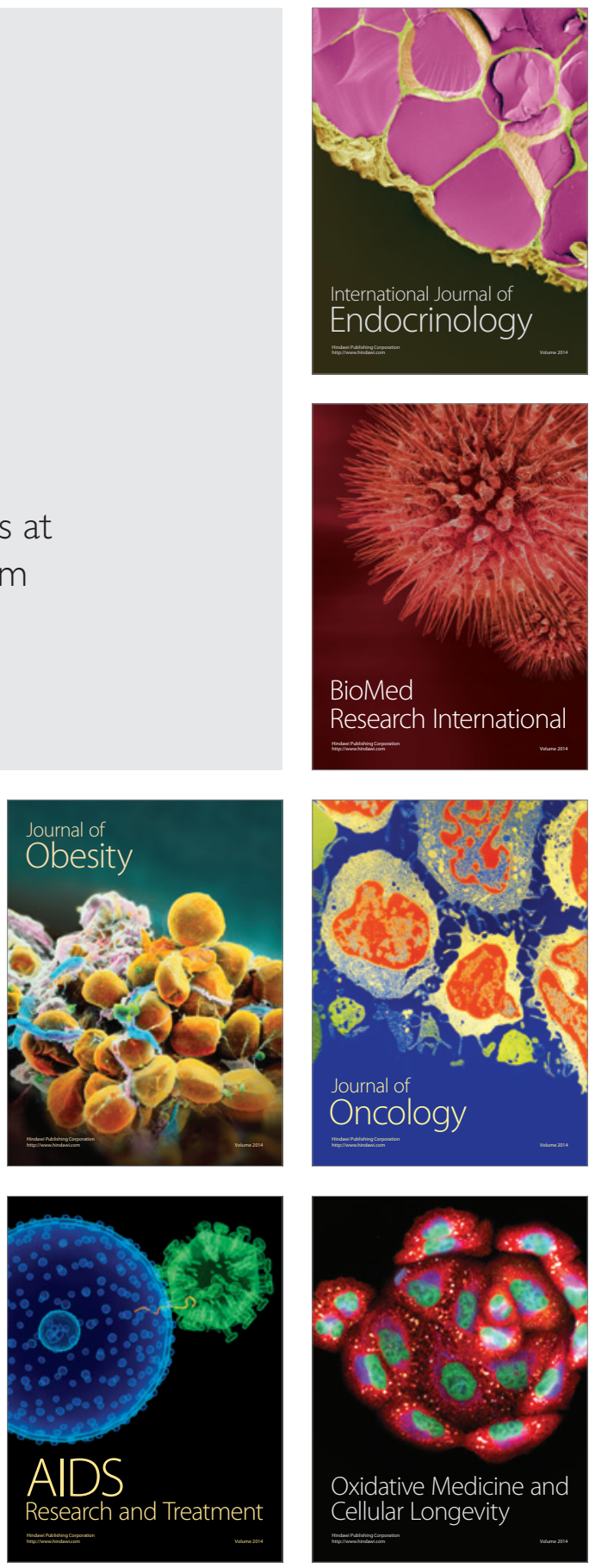